Ileen B. Malitz

Rutgers University

\title{
The Modern Role of Bond Covenants
}

The Research Foundation of

The Institute of Chartered Financial Analysts 


\section{Research Foundation Publications}

Active Currency Management

by Murali Ramaswami

Canadian Stocks, Bonds, Bills, and Inflation: 1950-1987

by James E. Hatch and Robert E. White

Closed-Form Duration Measures and Strategy Applications

by Nelson J. Lacey and Sanjay K. Nawalkha

Corporate Bond Rating Drift: An

Examination of Credit Quality Rating

Changes over Time

by Edward I. Altman and Duen Li Kao

Default Risk, Mortality Rates, and the Performance of Corporate Bonds

by Edward I. Altman

Durations of Nondefault-Free Securities by Gerald $\mathrm{O}$. Bierwag and George G.

Kaufman

Earnings Forecasts and Share Price

Reversals

by Werner F.M. De Bondt

The Effect of Illiquidity on Bond Price Data:

Some Symptoms and Remedies

by Oded Sarig and Arthur Warga

Equity Trading Costs

by Hans R. Stoll

Ethics, Faimess, Efficiency, and Financial Markets

by Hersh Shefrin and Meir Statman

Ethics in the Investment Profession: A Survey

by $\mathrm{E}$. Theodore Veit, CFA, and Michael R. Murphy, CFA

The Founders of Modern Finance: Their Prize-Winning Concepts and 1990 Nobel Lectures
Franchise Value and the Price/Earnings Ratio

by Martin L. Leibowitz and Stanley Kogelman

Initial Public Offerings: The Role of Venture Capitalists

by Joseph T. Lim and Anthony Saunders

A New Method for Valuing Treasury Bond

Futures Options

by Ehud I. Ronn and Robert R. Bliss, Jr.

A New Perspective on Asset Allocation

by Martin L. Leibowitz

Options and Futures: A Tutorial

by Roger G. Clarke

The Poison Pill Anti-Takeover Defense: The Price of Strategic Deterrence

by Robert F. Bruner

Predictable Time-Varying Components of International Asset Returns

by Bruno Solnik

Program Trading and Systematic Risk by A.J. Senchack, Jr., and John D. Martin

The Role of Risk Tolerance in the Asset Allocation Process: A New Perspective by W.V. Harlow III, CFA, and Keith C. Brown, CFA

Selecting Superior Securities

by Marc R. Reinganum

Stock Market Structure, Volatility, and Volume

by Hans R. Stoll and Robert E. Whaley

Stocks, Bonds, Bills, and Inflation:

Historical Returns (1926-1987)

by Roger G. Ibbotson and Rex A.

Sinquefield

(Published with Irwin Professional

Publishing) 


\section{The Modern Role of Bond Covenants}


(C) 1994 The Research Foundation of the Institute of Chartered Financial Analysts.

All rights reserved. No part of this publication may be reproduced, stored in a retrieval system, or transmitted, in any form or by any means, electronic, mechanical, photocopying, recording, or otherwise, without the prior written permission of the copyright holder.

This publication is designed to provide accurate and authoritative information in regard to the subject matter covered. It is sold with the understanding that the publisher is not engaged in rendering legal, accounting, or other professional service. If legal advice or other expert assistance is required, the services of a competent professional should be sought.

From a Declaration of Principles jointly adopted by a Committee of the American Bar Association and a Committee of Publishers.

ISBN 978-0-943205-77-9

Printed in the United States of America

January 1994 


\section{Mission}

The mission of the Research Foundation is to identify, fund, and publish research material that:

- expands the body of relevant and useful knowledge available to practitioners;

- assists practitioners in understanding and applying this knowledge; and

- enhances the investment management community's effectiveness in serving clients.

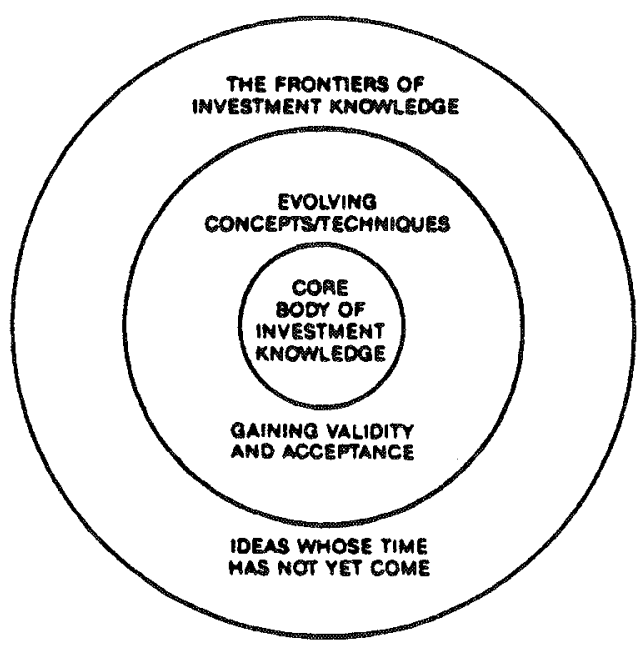

The Research Foundation of

The Institute of Chartered Financial Analysts

P. O. Box 3668

Charlottesville, Virginia 22903

U.S.A.

Telephone: 804/977-6600

Fax: 804/977-1103 


\section{Foreword}

The growing popularity of corporate debt as an investment vehicle emphasizes the importance of knowledge about types of bond covenants, the protection they provide, and their use in practice. In this study, Malitz carefully examines the occurrence and characteristics of covenants contained in current bond indentures.

Malitz begins with an analysis of conflicts among the corporation's owners, managers, and creditors. The heightened incidence of leveraged buyouts, mergers and acquisitions, stock repurchases, divestitures, spin-offs, sell-offs, and the like since the early 1970 s has increased awareness of the potential conflicts of interest between different corporate claimants-particularly between stockholders and bondholders, who claim different portions of a firm's return distribution. In this monograph, Malitz identifies these conflicts of interest and the ways in which owners or managers can expropriate bondholders' wealth.

In the recent past, bondholders often looked toward bond covenants to protect their financial interests. The bond indenture specifies the contractual obligations and rights of each claimant. Most indenture provisions are standard legal specifications, but specific covenants may also be included that are designed to control the conflicts of interest between shareholders and bondholders and to protect the creditors against wealth expropriation.

Before conducting an empirical investigation of bond covenants, Malitz identifies and describes the specific covenants available to protect corporate creditors. She analyzes a range of types - from such traditional covenants as sinking funds, seniority, call features, and various restrictions to such recent protective innovations as event-risk and credit-sensitive covenants.

Malitz concludes the study with a detailed examination of the indentures for a sample of 414 corporate bonds issued from 1960 through 1992 . The results provide an abundance of knowledge about the characteristics of corporate debt. Of particular interest is the fact that not all findings conform to conventional beliefs. For example, specific-event-risk covenants, which surged in use following the RJR Nabisco leveraged buyout, have all but disappeared, and they have not been replaced by new covenants. Also, the recent disappearance of sinking-fund provisions is surprising. What is the explanation for the vanishing restrictive covenants? Malitz addresses this question and many more and, in doing so, provides valuable and useful information to both bond issuers and bond purchasers.

It is with great pleasure that the Research Foundation brings this important work on bond indentures to its worldwide constituency.

John W. Peavy III, CFA 


\section{Acknowledgments}

This research was supported by a grant from the Research Foundation of the Institute of Chartered Financial Analysts. I would like to thank Dick Wilson of Fitch Investment Services for his invaluable background information and Michael S. Long for his help, support, suggestions, and cheerful repeated readings of the manuscript.

Ileen B. Malitz 


\section{The Modern Role of Bond Covenants}

On November 30, 1988, Kohlberg Kravis Roberts was declared the winner in a contested bid for the leveraged buyout (LBO) of RJR Nabisco. The LBO was to be financed almost exclusively with debt-junk bonds, bank loans, and bridge financing (private placements). The deal proved a success for most parties. Shareholders clearly gained; they received a total (in cash and securities) of approximately $\$ 109$ per share for stock that sold for $\$ 53$ before the bidding war began on October 20, 1988.

Most analysts believe that the only clear-cut losers were RJR's original creditors. In December 1987, before the first announcement of LBO plans, RJR had 25 public debt issues with a par value of $\$ 3.601$ billion, $\$ 1$ billion of which was issued in 1987. At year-end 1988, RJR's long-term debt had crept up to $\$ 4.475$ billion, but only one year later, the company's outstanding debt was $\$ 22.774$ billion-an increase of 532 percent.

The enormous increase in leverage (from 24 percent to 63 percent of total assets and from 32 percent to more than 100 percent of tangible assets) raised the bondholders' risks tremendously. At the outset of the bidding war, on October 20,1988, the value of RIR's public debt fell approximately 14 percent in anticipation of this huge increase in leverage. After the buyout, Metropolitan Life, a major private holder of RJR debt, brought a creditor suit. Met Life lost the suit, however. The judge ruled that Met Life was a sophisticated investor and, as such, could be expected to anticipate events such as an LBO; Met Life should have insisted on protection. The case was appealed and was settled out of court prior to a final ruling.

The RJR Nabisco LBO was the latest chapter in the book of junk-bondfinanced takeovers during the 1980s. The extensive use of junk bonds had eroded the value of existing bonds and caused major reductions in bondholder wealth. The consequence was a widespread belief that existing bond covenants 
had not protected bondholders and that new, innovative covenants were needed. Underwriters of both public and private debt issues rushed to develop new covenants to protect creditors involved in similar transactions. The result was a new set of "event-risk" restrictive covenants protecting creditors from specific events. These covenants generally give creditors the option of selling back (putting) their debt at a stated price or resetting the interest rate if specified events take place. Some covenants require that the specified event be accompanied by a rating downgrade. Regardless of the exact terms, all such covenants have one thing in common: They offer protection only against the specified events; unforeseen future events are not included.

Consider the experience of the Marriott Corporation and its creditors. On October 5, 1992, Marriott announced a division of the company into two separate entities-Host Marriott, consisting of properties owned by Marriott, and Marriott International, the management corporation. All of Marriott's $\$ 2.4$ billion debt would be transferred to Host Marriott. On the basis of 1991 financial data, Host Marriott would incur interest expenses of $\$ 225$ million-almost two-thirds of its operating cash flow. On the announcement day, the price of Marriott's public debt dropped an average of 30 percent.

Marriott's private institutional creditors reacted immediately. Although none of Marriott's debt provided protection against restructurings of this type, eight class-action lawsuits were filed. On March 11, 1993, Marriott announced an altered restructuring plan with better terms for current bondholders. Marriott agreed to move $\$ 450$ million of debt from Host Marriott to Marriott International. Agreements were signed with all but one creditor, PPM America, Inc. PPM America held more than $\$ 120$ million of Marriott debt, issued in April 1992, and sued the company for securities fraud. ${ }^{1}$

Would an event-risk covenant have protected Marriott's creditors? Because a restructuring of the type contemplated by Marriott (transferring all debt to the less profitable company) had never previously been proposed, creditors were unlikely to have written (or even thought of) a covenant covering such an event. In effect, event-risk covenants, providing protection against events experienced in the past, can only be backward looking.

Writing covenants for every possible contingency would not, of course, be feasible and would probably be ineffective. Anticipating all possible actions by owners is virtually impossible. Even if an indenture were to itemize every possibility, the U.S. courts are unlikely to enforce such restrictions. For

\footnotetext{
${ }^{1}$ The Marriott restructuring became effective on October 11, 1993. As of December 1993, the PPM America suit had not been resolved.
} 
example, even when bonds have clear seniority, bankruptcy courts rarely enforce absolute priority unless the debt is specifically secured.

Because corporate debt is a major source of investment funds, knowledge about types of bond covenants, their intended protection, and their use in practice is extremely important for any investor contemplating a bond portfolio. The incidence and characteristics of covenants that have been written since the 1960 s is the subject of this study.

This study is an analysis of the bond indentures of 414 long-term public debentures issued between 1960 and 1992. The incidence of each covenant was recorded, and differences over time are examined. Characteristics of the offering firms are compared across sets of covenants and across time. The study concludes that bondholder losses in the 1980s were primarily attributable to a lack of protection rather than to a deficiency in traditional covenants per se.

The study is organized as follows. The first section contains a review of the potential conflicts of interest between shareholders and bondholders (owners and creditors), to which covenants are directed. In the following section, the role of specific covenants in protecting creditors is analyzed. This section draws heavily on the 1971 study by the American Bar Foundation, Commentaries on Model Debenture Indenture Provisions 1965, Model Debenture Indenture Provisions, All Registered Issues 1967 and Certain Negotiable Provisions Which May Be Included in a Particular Incorporating Indenture (hereafter, Commentaries). Each traditional and new covenant is discussed separately. This section also contains a review of literature relevant to the need for, and the protection provided by, traditional covenants. The final two sections present the empirical evidence from the study conducted for this monograph and the conclusions.

\section{Conflicts of Interest between Owners and Creditors}

Bond covenants are designed to control the conflicts of interest between shareholders and bondholders. Shareholders and holders of risky debt claim different portions of a firm's return distribution. Bondholders have a fixed claim representing the lower portion of the firm's returns. Shareholders hold claims to all (or any) cash flow remaining after creditors' claims are satisfied (the upper portion of the return distribution). As each group seeks to maximize its own wealth, conflicts of interest arise that sometimes lead shareholders to expropriate the wealth of creditors.

The terms of covenants are important both because they are part of the bond indenture (hence, they constitute legal agreements restricting, or requiring, future actions of the firm) and because lack of adequate protection can erode bondholder value. In the extreme case, violation of covenants results in technical default. 
Jensen and Meckling's important 1976 paper on the theory of the firm views the firm as a legal fiction that serves as a vehicle for contracting relationships. ${ }^{2}$ The firm, in effect, consists of residual claims on assets and cash flows. These claims can be bought or sold by one contracting party without permission of other contracting parties. This situation sets the stage for potential conflicts of interest between different claim holders.

One major class of potential conflicts is "agency" relationships. Jensen and Meckling define the agency relationship as "a contract under which one or more persons (the principal[s]) engage another person (the agent) to perform some service on their behalf which involves delegating some decision-making authority to the agent" (1976, p. 308). The authors discuss two agency relationships that can result in conflict and consequent cost to the firm:

- Agency costs of outside equity reflect conflicts of interest between outside owners (shareholders or principals) and inside owners (managers or agents). Because managers may have different goals from shareholders, some managerial actions may reduce share value. To protect their jobs, for example, managers may fight a takeover bid even though shareholders would benefit from the bid premium.

- Agency costs of debt relate to conflicts between debtholders and shareholders (or managers acting on the behalf of shareholders). ${ }^{3}$ Managers may have incentives to undertake actions whose costs are borne by the creditors and whose gains are reaped by the owners. Such actions expropriate wealth from creditors.

Owners (or managers) can expropriate creditors' wealth in at least three ways - underinvestment, asset substitution, and claim dilution. Each of these forms results in a loss in debt value.

Underinvestment Myers (1977), building on Black and Scholes (1973), formalized managers' (owners') incentives to underinvest-that is, to fail to invest in projects that are profitable from an economic standpoint. ${ }^{4}$ When the

\footnotetext{
${ }^{2}$ Jensen and Meckling's (1976) work draws heavily on the property rights literature of economics, including Alchian (1965) and Berle and Means (1933).

${ }^{3}$ Even though conflicts also exist between owners and managers (who make the decisions in corporations), the assumption is that, when dealing with creditors, managers are more likely (and are required by their fiduciary role) to act on behalf of owners, particularly in the case of conflict between owners and creditors.

${ }^{4}$ In Black and Scholes's option-pricing model, a firm's equity is a call option on the firm's total value and debtholders are the option writers. Viewed in this manner, creditors cannot share in
} 


\section{TABLE 1. Cash Flows from Investment Choices:} No Constraints

\begin{tabular}{|c|c|c|c|c|}
\hline Scenario & At Time 0 & $\begin{array}{l}\text { At End of } \\
\text { Year } 1\end{array}$ & $\begin{array}{l}\text { At End of } \\
\text { Year } 2\end{array}$ & $\begin{array}{c}\text { Net Cash } \\
\text { Flow after } \\
\text { Year } 2\end{array}$ \\
\hline \multicolumn{5}{|c|}{ Panel A: Cash flows from two investments } \\
\hline From initial investment & -100 & 150 & 50 & 100 \\
\hline From optional investment & $\underline{0}$ & -75 & $\underline{100}$ & 25 \\
\hline $\begin{array}{l}\text { Net cash flow from two } \\
\text { investments }\end{array}$ & -100 & 75 & 150 & 125 \\
\hline \multicolumn{5}{|c|}{$\begin{array}{l}\text { Panel B: Net cash flows when bondholders supply initial investment and shareholders } \\
\text { take investment option }\end{array}$} \\
\hline Bondholder cash flows & -100 & 0 & 100 & 0 \\
\hline Stockholder cash flows & 0 & 75 & 50 & 125 \\
\hline \multicolumn{5}{|c|}{$\begin{array}{l}\text { Panel C: Net cash flows when bondholders supply initial investment and shareholders } \\
\text { do not take investment option }\end{array}$} \\
\hline Bondholder cash flows & -100 & 0 & 50 & -50 \\
\hline Stockholder cash flows & 0 & 150 & 0 & 150 \\
\hline
\end{tabular}

cash flow generated from an investment might go to creditors rather than to owners, owners may be better off if managers choose not to invest.

Consider a simple case. Assume no time value of money, perfect certainty, and a two-year time frame. The firm starts out with a $\$ 100$ investment. The initial asset base generates cash flows of $\$ 150$ at the end of Year 1 and $\$ 50$ at the end of Year 2. An opportunity exists, however, to invest $\$ 75$ at the end of Year 1 and receive an additional return of $\$ 100$ at the end of Year 2; if the investment is not taken, the opportunity is lost. Table 1, Panel A, summarizes these investments. Clearly, both the firm and the economy are better off if the $\$ 75$ investment is made: It adds $\$ 25$ to value.

Now suppose the firm raises the $\$ 100$ for the asset base through debt financing. It creates a creditor claim of $\$ 100$ due at Year 2. To keep the firm's size constant, assume the firm's owners borrow the $\$ 100$ and distribute the

increases in firm value but can experience a loss in value. For example, because share value increases with the variance of cash flows, shareholders have incentives to select high-variance (risky) projects, which reduce debt value. The value of current debt is also reduced when firms issue new debt of the same or equal priority. 
cash to themselves through an exchange offer. At the end of the first year, the owners (shareholders) again face the choice of whether to invest or not. They will presumably choose the option that provides the greatest increase to their own wealth.

If they invest, the owners will receive $\$ 75$ from the net cash flows of the firm in Year 1 ( $\$ 150$ less the $\$ 75$ investment) and $\$ 50$ from the cash flow in Year 2 ( $\$ 150$ less the $\$ 100$ payment to debtholders), for a total of $\$ 125$. Bondholders receive the $\$ 100$ they lent, for a net value gain of zero. Table 1 , Panel $B$, shows these payouts.

Panel $\mathrm{C}$ in Table 1 shows the payouts if shareholders choose not to make the additional $\$ 75$ investment. In this case, shareholders receive the entire $\$ 150$ cash flow in Year 1 and nothing in Year 2. Creditors are left with a claim paying only $\$ 50$, however, for a net value of $-\$ 50$. Total firm value decreases by $\$ 25$ relative to the $\$ 125$ value in the case of the $\$ 75$ being invested. The loss in value is borne by the shareholders, but they have also effectively expropriated $\$ 50$ from the creditors; so their net wealth gain from the investment is $\$ 25$.

Such a scenario creates a problem, however. Unless shareholders are assumed to know more about future claims than creditors, creditors will correctly anticipate the probability that their wealth might be expropriated and the loss in debt value that will result. Therefore, bondholders will not be willing to pay $\$ 100$ but, rather, will pay only the "true" $\$ 50$ value. Shareholders will then need to make up the 50 percent difference, and their claim will be worth only $\$ 100$. In other words, shareholder wealth is (and always will be, in a rational world) equal to firm value. And, because firm value declines when investments with positive net present values (NPVs) are not made, shareholders are better off investing.

The result is a problem for the shareholders: How do they convince potential bondholders that the shareholders will invest? Why should bondholders believe them? After all, what is to stop the owners from collecting the $\$ 100$ and then "forgetting" to invest? What type of guarantee can be offered that is believable by everyone concerned? One way to provide a believable guarantee is to restrict the firm's payout.

Suppose that, as in the original case, the firm raises the initial $\$ 100$ through debt financing and is not allowed to pay a dividend (or repurchase shares) unless bondholders are repaid in full or unless the investment at the end of Year 1 is made to ensure that cash flow in Year 2 is sufficient to repay debtholders in full. Table 2, Panel A, shows the payoffs under this constraint if the investment option is not taken.

The $\$ 150$ cash flow available at the end of Year 1 (see Table 1, Panel C) cannot be distributed to shareholders, because they neither invested the 


\section{TABLE 2. Cash Flows from Investment Choices: Constraints}

\begin{tabular}{cccc} 
& & & Net Cash \\
Scenario & At End of & At End of & Flow after \\
At Time 0 & Year 1 & Year 2 & Year 2 \\
\hline
\end{tabular}

Panel A: Net cash flows when bondholders supply initial investment and shareholders do not take investment option

Cash available for distribution

Bondholder cash flows

$-100$

0

200

NA

Stockholder cash flows

$-100$

100

0

0

100

100

Panel B: Net cash flows when bondholders supply initial investment and shareholders take investment option

Bondholder cash flows

Stockholder cash flows

$$
-100
$$

0

100

$\mathrm{NA}=$ not applicable.

proceeds from the debt sale nor paid the creditors. Only at the end of Year 2 , after creditors have been paid in full, can the $\$ 100$ dividend be paid. The shareholders' total wealth is $\$ 100$; the bondholders' claim has a net value of zero (as it should have).

Now suppose the investment is made at the end of Year 1. Because shareholders invest the proceeds and ensure that debt can be repaid in full, they can pay out the excess cash at the end of Year 1 . Their total wealth is higher with the investment under the constraints, and they will thus choose to invest optimally. The payoffs are shown in Table 2, Panel B.

In the real world, incentives to underinvest arise whenever a firm faces the possibility that it may have to default. Because they face only limited liability, shareholders, if unconstrained, may find it more profitable to stop investing (stop using their own money) and simply pay out any available cash as dividends or use it for share repurchase. The payment of large, unexpected dividends or a major share repurchase have long been recognized by creditors as an action that can harm and erode their claims.

Asset Substitution. Asset substitution, or risk shifting, represents a second potential conflict of interest between bondholders and stockholders. Bondholders buy debt expecting the proceeds to be used for projects of specified risk. If shareholders substitute projects that are riskier than those understood by the creditors, in effect, they transfer wealth from creditors to themselves. 
Suppose a firm issues $\$ 100$ in debt to fund an investment of known risk. Again, to hold firm size constant, assume that the proceeds from the sale of debt are distributed to shareholders. Creditors agree to pay $\$ 100$ for the debt, because they expect the project to generate the following state-dependent NPVs (payoffs net of investment lost):

$$
0.5(\$ 100)+0.5(\$ 200)=\$ 150 \text {. }
$$

Because the firm has only one project, this NPV is also the firm's value. Bondholders have a riskless claim, in the sense that they will receive the full value of their claim (that is, $\$ 100$ ) whether the eventual NPV is $\$ 100$ or $\$ 200$. Shareholders have a riskier claim, in that they will receive nothing if the project is worth only $\$ 100$ but will receive $\$ 100$ if the project is worth $\$ 200$. Given the $50 / 50$ probabilities of the two NPVs, the expected value of the project for shareholders is

$$
0.5(\$ 100-\$ 100)+0.5(\$ 200-\$ 100)=\$ 50 .
$$

In addition, shareholders have the $\$ 100$ raised from the sale of debt, for a total wealth of $\$ 150$.

Now suppose that, after debt is sold, the shareholders change their minds and decide to invest in a project that is much riskier than the one described. This project has a potential NPV of $\$ 1,000$-five times the size of the higher of the two potential NPVs of the initial project. The probability that the project will reach this NPV is only 10 percent, however; the probability that the project will turn out to be worthless is 90 percent. The value of this project is

$$
0.9(0)+0.1(\$ 1,000)=\$ 100,
$$

which is $\$ 50$ less than the value of the initial project. Furthermore, because bondholders receive repayment worth only $\$ 100$, even when the outcome is good, and there is only a 10 percent chance of a good outcome, their claim is worth only $\$ 10$ (that is, $0.1[\$ 100]$ ). Because of the shift to a riskier project, bondholders have lost $\$ 90$ relative to the initial amount they paid for the debt.

The value of the risky project to shareholders is

$$
0.9(0)+0.1(\$ 1,000-\$ 100)=\$ 90,
$$

which is $\$ 40$ more than the value of the initial project to shareholders. Their wealth also increases by $\$ 40$, to $\$ 190-\$ 90$ from the project and $\$ 100$ proceeds from the sale of debt. Shareholders gain $\$ 40$ by expropriating $\$ 90$ from bondholders and bearing the $\$ 50$ loss in firm value.

As with underinvestment, the likelihood of risk shifting increases as default likelihood increases and as debt payments rise. Shareholders are more inclined 
to go for broke when they have nothing to lose. After all, if the project fails, the firm is bankrupt and the creditors, not the shareholders, pay for the investment.

- Claim dilution as a subset of asset substitution. Obvious attempts to go for broke are not the only way creditors' claims can be eroded. Shareholders can also issue additional debt with seniority the same as or greater than that of outstanding debt. This action dilutes the original creditors' claims and, in effect, expropriates a portion of their wealth. Fama and Miller (1972) identified the problem of claim dilution and discussed "me-first" rules whereby current debtholders would always have strict seniority over any future debt claims. Brick and Fisher (1987) found that, prior to 1950, most indentures prohibited the firm from assuming any further debt of equal or greater priority. By 1976, however, such covenants had virtually disappeared. Even if such rules were written, they would almost never be enforced. ${ }^{5}$ Note that pure claim dilution does not affect investment policy (as asset substitution does). Only leverage changes. Because it affects only the redistribution of assets, not the firm's investment decisions, pure claim dilution does not affect firm value. ${ }^{6}$

Most of what is commonly considered to be claim dilution actually involves investment policy. Therefore, it represents the systematic and purposeful increase of risk (asset substitution) rather than a dilution of claims. The debt issued to finance LBOs, for example, is not an example of pure claim dilution, even though it does have the effect of diluting claims. Rather, it constitutes a major change in investment policy and a systematic increase in the risk borne by original creditors. The actual claim dilution is incidental to a (potentially value-increasing) investment decision. To be strictly accurate, this monograph will treat claim dilution as asset substitution or risk shifting.

- Controlling asset substitution. Although the courts might step in to protect creditors in cases of pure claim dilution, they are not likely to interfere. with a firm's investment policy, particularly if the resulting investments, although creating creditor losses, increase firm value. ${ }^{7}$ The firm itself, however, can control asset substitution in two possible ways.

\footnotetext{
${ }^{5}$ The issue of priority for firms reorganizing under Chapter 11 is discussed in the next section.

${ }^{6}$ Although, in theory, pure claim dilution is possible, I have not been able to uncover any actual instances of new debt of the same or higher priority being issued and immediately paid out to owners. Even the Marriott restructuring, which on the surface looks like claim dilution, is actually an investment decision. Restructurings of the type proposed by Marriott have been shown to increase overall firm value, in which case, they are good for the economy.

${ }^{7}$ Recall that Met Life lost the suit against RJR Nabisco. What, if anything, the courts might do in the PPM America suit against Marriott Corporation is, of course, not yet known.
} 
First, the firm can issue convertible debt. Allowing creditors to share in gains to firm value reduces incentives to expropriate creditor wealth and mitigates risk shifting.

Second, the firm can limit debt. The more debt a firm has, the more shareholders can gain from expropriating creditors' wealth. Limiting leverage reduces adverse incentives.

Consider again the asset-substitution example. Suppose leverage is limited to 30 percent of (initial) firm value, or $\$ 45$. With the low-risk project, the shareholders' claim is then worth

$$
0.5(\$ 100-\$ 45)+0.5(\$ 200-\$ 45)=\$ 105 \text {. }
$$

With the riskier investment, however, the shareholders' claim is worth only

$$
0.9(0)+0.1(\$ 1,000-\$ 45)=\$ 95.50 \text {. }
$$

Shareholders have wealth of $\$ 150$ with the low-risk project and only $\$ 140.50$ with the high-risk project. Therefore, they are better off staying with the low-risk project; bondholders thus get repaid, and both firm value and economic wealth are maximized.

Ex post losses are borne by bondholders, but in a rational market, any loss in ex ante firm value is borne, at least to some extent, by shareholders. Therefore, it may be in the interests of both parties to minimize total potential losses.

\section{The Bond Indenture and Firm-Specific Covenants}

A bond indenture is a legally binding contract between the issuing firm and creditors. It spells out in detail all the contractual obligations and rights of each party. Violation of the terms of the covenants can lead to technical default, with the same consequences as a formal default on principal and interest payments. Thus, the specific terms of indentures are not to be taken lightly, particularly for public debt. ${ }^{8}$

Many of the provisions in an indenture are standard legal specifications. They include definitions, the form of the securities issued and their denominations, legal remedies, required reports, registration requirements, rights in default, and designation of the trustee under the Trust Indenture Act of 1939. They also include specification of the interest rate, maturity, and call provision

\footnotetext{
${ }^{8}$ Kahan and Tuckman (1993) show that privately placed debt is more restrictive than public issues. The reason is that the fewer the debtholders, the simpler and less expensive renegotiating covenant terms is.
} 
(if any) of the debt. Of direct relevance to this study are the specific covenants designed to control the conflicts of interest between shareholders and bondholders and to protect creditors against wealth expropriation or dispossession.

Covenants can be either positive or negative. Positive covenants require the firm to engage in specific actions such as planning for the orderly retirement of debt through a sinking fund. Negative covenants prohibit the firm from engaging in specific actions such as issuing secured debt. Both are commonplace, and neither is costless. All covenants, by reducing future managerial flexibility, reduce the firm's ability to respond to future changes. The choice of whether or not to include specific covenants depends on the characteristics of the firm.

Historical Covenant Protection and Previous Studies. McDaniel (1988) notes that, prior to the 1920 s, states tried to regulate corporate debt through their incorporation laws. For the most part, in the 1800 s and early 1900 s, states limited corporate debt to an amount equal to capital stock, or 50 percent of total capital. In part because they were considered arbitrary and not reflective of the needs of specific corporations, such statutory restrictions on debt were dropped by the 1930 s. Since then, they have been gradually replaced by restrictive covenants contained in bond indentures.

Covenants initially represented an improvement over the statutory arrangements. They could be (and were) written to be very firm specific, but this specificity made it extremely difficult for investors to interpret and evaluate individual covenants or compare covenants written by different underwriting firms. Furthermore, many covenants used a net-worth test (a form of dividend restriction) based on a dollar amount of stockholders' equity. This approach led to problems, of course, if firms merged (which made the restrictions meaningless) or restructured their assets (which led to covenant violations).

By the late 1950s, both the legal profession and corporations recognized that some type of standardization of covenants was required. The American Bar Foundation established a committee to review the issue, and in 1967, this committee published Commentaries, which standardized the wording of covenants in the format of most covenants written since World War II.

Based on the work in Commentaries, Smith and Warner (1979) identified four major sources of the bondholder-stockholder conflict-underinvestment, distributions to owners, claim dilution, and asset substitution ${ }^{9}$-and discussed

${ }^{9}$ As discussed, claim dilution is a subset of asset substitution. Kalay (1982) showed that underinvestment frees up funds to distribute to owners. Thus, distribution to owners is a subset (or cause) of the underinvestment problem. 
the provisions of bond indentures intended to control the conflicts. Specifically, Smith and Warner reviewed the following four types of debt covenants:

- Restrictions on the firm's production/investment decisions. These covenants, which limit and specify the particular projects in which a firm can invest, are generally implicit controls rather than direct restrictions on investment policy. They include restrictions on investments in other firms' securities, restrictions on the disposition of a substantial portion of the firm's assets, restrictions on mergers, and maintenance covenants. This form of restriction is present in most indentures. ${ }^{10}$

- Bonding requirements. These requirements include reporting, auditing, and accounting procedures; insurance requirements; and certifications of compliance with all covenants. Such provisions are present in all indentures and are not discussed further here.

- Restrictions on distributions to owners. In this type of restriction, distributions (including share repurchases) may be made only out of additions to retained earnings. This restriction is discussed at length later.

- Resirictions on subsequent financing policy. These restrictions limit future funded debt, secured debt, and/or the sale and leaseback of assets. Sinking funds, convertibility, and call provisions also restrict future financing. According to Smith and Warner, these covenants are designed to control the dilution of creditors' claims (a subset of asset substitution).

Smith and Warner (1979) identified two alternative hypotheses related to the effect of debt covenants-the irrelevance hypothesis and the costly-contracting hypothesis. The irrelevance hypothesis asserts that, when the level of investment is fixed, the value of the firm is independent of the level of debt. When the total dollar amount of investment is allowed to vary, the irrelevance of the level of debt may not hold. Even then, however, if external market pressure is sufficient, or if claims can be restructured without cost, capital structure (hence, the form of specific claims) remains irrelevant.

The costly-contracting hypothesis asserts, alternatively, that the form of financial contracts can affect firm value. Specifically, if debt contracting is costly, then the use of specific covenants involves a trade-off between the benefits of covenants (including the increase in debt and firm value) and the costs of monitoring, bonding, and enforcing the covenants, as well as the reduction in

\footnotetext{
${ }^{10}$ Moody's does not accurately report the incidence of these restrictions (Asquith and Wizman 1990), and because examining more than 400 individual indentures was not feasible, restrictions on subsequent investment policy are not explicitly addressed in this monograph.
} 
managerial flexibility. The costly-contracting hypothesis suggests that an optimal set of covenants exists that maximizes firm value.

Smith and Warner's 1979 study supported the costly-contracting hypothesis and offered a rationale for the substantial variation in debt covenants among firms. They concluded, "Observed debt covenants reduce the costs associated with the conflict of interest between bondholders and stockholders" (p. 152).

Smith and Warner's work led to a growing body of literature examining covenants. As will be discussed in a later section, some studies, such as those of Brauer (1983) and Roberts and Viscione (1984), examined whether the market prices of securities reflect bond covenants, as the costly-contracting hypothesis would predict. Other researchers took the approach of investigating whether existing covenants exhibit consistent patterns. Kalay (1982), for example, identified the characteristics that would lead a firm to offer a dividend restriction; Thatcher (1985) examined the call provision.

In a 1982 study, Malitz investigated the differences between firms issuing debentures with both dividend and debt restrictions and those issuing debentures without either restriction. The study used a sample of 252 senior, nonconvertible, industrial debentures issued by publicly traded firms between 1960 and 1980. Fifty-seven percent of the issues contained at least one of the covenants (dividend or debt restriction); the vast majority ( 86 percent) included both.

The 1982 study noted that incentives for underinvestment and risk shifting (hence, the agency costs of debt) should increase with the probability of default. One determinant of the need for any constraining debt covenants should be, therefore, the level and variability of future expected earnings. A second, perhaps more important, indication of the need for constraints should be the firm's reputation, particularly in the capital markets. In particular, investors regularly review the actions of a firm that frequently enters the debt market. If such a firm has engaged in wealth expropriation in the past, or if the firm's opportunity set has recently shifted, potential bondholders' estimates of associated agency costs may be high enough that the firm's owners would benefit by offering debt restrictions. These restrictions might also, of course, benefit original debtholders.

The 1982 study used discriminant analysis to predict the optimal set of covenants for each firm and issue. The major determinants of a limitation on future debt and dividends in an indenture were the firm's reputation, as proxied by its size and experience in the debt market, and its leverage prior to issuance of the new debt. Firms with both covenants were found to be less profitable, riskier (higher variance), smaller, and more leveraged (prior to debt issuance) and to have lower growth and more intangible assets than firms with no 
covenants. These variables can be used to predict a firm's set of bond covenants with 82 percent accuracy. The conclusions are (1) that small firms, those with little market experience, and firms with high initial leverage would benefit from offering dividend and debt restrictions and (2) that all firms should offer a sinking fund.

Mitchell's 1991 study examined the simultaneous choice of call, sinking fund, and term to maturity in the issuance of corporate bonds. The author found that new firms and those with relatively numerous investment opportunities issue short-maturity debt (and debt without calls or sinking funds). She also found that firms listed on the New York Stock Exchange (NYSE) or included in the Standard \& Poor's 400 issue longer term debt than other firms. Her results are consistent with reputation being a major determinant of debt features. The more well known the firm and the better its reputation, the fewer restrictions its debt should require.

The public statements by Marriott's top management in the wake of Marriott's announcement that the company would split into two corporations provides evidence that reputation is important. During February and early March 1993, Chairman J.W. Marriott, Jr., spoke of the importance of maintaining Marriott's reputation in the marketplace. Then, on March 11, 1993, Marriott publicly announced the revised proposal in which new bonds plus cash would be exchanged for the original bonds, and $\$ 450$ million of the debt would be shifted from Host Marriott to Marriott International.

Eastman and Viswanath (1992) addressed another aspect of covenants, covenants in the context of the legal system. They noted that the U.S. courts, viewing bondholder rights as purely contractual, have continually rejected the position that corporations owe a fiduciary duty to bondholders. The courts may go beyond the explicit provisions of a contract, however, by invoking the implied covenant of good faith and fair dealing. Eastman and Viswanath discussed this implied covenant in the specific context of the Met Life-RJR Nabisco suit. In ruling against Met Life, the court acknowledged the existence of an implied covenant but rejected the claim that RJR Nabisco had violated it. As noted previously, the court's ruling was based, in part, on its view of Met Life as a sophisticated institutional investor; the door is presumably still open for a less sophisticated investor to seek remedy in some future case.

Eastman and Viswanath addressed whether bondholder protection should be limited to what is explicitly enumerated (rules) or, rather, should allow for the application of judicial rulings based on a fiduciary obligation to bondholders (standards). They concluded that a combination of rules and standards was needed to protect bondholders. In their view, event-risk provisions are worrisome on two counts: They attempt to anticipate the future, and they 
preclude value-increasing events. Eastman and Viswanath maintained that, at the time of contracting, all possible actions that might harm debtholders cannot be anticipated. Moreover, even if they could be anticipated, many actions increase firm value and, therefore, should not be precluded by event-specific provisions.

Specific Covenants. Covenants of different types play different roles in controlling conflicts of interest. The specific covenants discussed here are seniority, the call provision, the sinking fund, the negative pledge, restrictions on sale/leaseback of assets, limitations on distributions to shareholders (dividend restrictions), and limitations on debt.

- Seniority. The bond indenture clearly states the seniority of the debt. All debt is senior to shareholders' equity and junior to the claims of other stakeholders (employees and the government). Debt can be senior or subordinated, and it can be subordinated to various degrees. In theory, senior debt should take precedence over subordinated debt; that is, it must be paid in full before any payments to subordinated debtholders are made.

Many covenants allow for corporate restructurings such as mergers as long as any original debt is "equally and ratably secured" with the new debt. ${ }^{11}$ This limitation does not protect the original creditors, because the new debt still represents unsecured claims on the general assets of the firm, which are subject to violations of absolute priority.

Violations of absolute priority occur because bankruptcy courts operate under the doctrine of fairness, or "equity"; thus, absolute priority is almost never followed in practice. Most recent Chapter 11 filings have led to violations of absolute priority. Holding a senior (rather than subordinated) claim, therefore, does not provide total protection; nor, contrary to common assumptions, is subordinated debt on the same level as (or even similar to) equity. ${ }^{12}$

Violations of absolute priority may have influenced the use of covenants in general. If creditors believe that an indenture will not be upheld in court, they may be less concerned about what it contains than they would otherwise be. The violations may thus reduce creditors' reliance on covenants and may have influenced the use of covenants in general. This possibility is discussed again in

\footnotetext{
${ }^{11}$ Equally and ratably secured means that the debt carries the same priority standing as it did originally.

${ }^{12}$ For a more complete analysis of violations of absolute priority and their effect on creditors' wealth, see Malitz and Cohn's 1987 study of Wickes Companies and Duplan Company.
} 
relation to the current study's findings, but a full analysis is beyond the scope of this study.

- The call provision. Unlike other covenants, a call protects the debtor rather than the creditor. A call provision allows the firm to retire debt prior to maturity. It is usually invoked when interest rates drop substantially below the bond issue's rate.

To compensate debtholders for the possibility of the debt being called, most callable bonds pay a premium over par; this premium declines as the bond approaches maturity. In addition, most calls cannot be called for a specified number of years. Protection from early call may apply to all calls, or it may prohibit only calls designed to refund the debt at a reduced interest rate (a two-tiered call).

Thatcher (1985) suggested that the existence of two-tiered calls implies reasons other than interest rate changes for a call provision. Specifically, she examined the use of a call to realign shareholders' interests and reduce adverse investment incentives. Thatcher predicted that firms with high growth, high debt, and low profitability (indicating high default risk) would benefit by offering a two-tiered call provision. Her sample consisted of 118 debt issues of varying maturity, 85 with a two-tiered call and 33 with a regular call feature. Using discriminant analysis, she was able to classify debt issues with 78 percent accuracy.

- The sinking fund. A sinking fund serves two primary purposes. First, it limits the amount of debt outstanding by pushing payments to bondholders forward in time and thereby minimizing bondholders' risks. For a financially shaky firm, a sinking fund may force default to occur sooner than it would have if the entire principal payment were deferred until maturity. Upon transfer of the firm under bankruptcy, bondholders hold claim to the expected future value of all assets in place and of any firm growth opportunities. They may then invest optimally without fear of underinvestment or asset substitution.

A sinking fund also serves to reduce discretionary investments with negative economic value by reducing the firm's free cash flow. ${ }^{13}$ This function is particularly important when firms have few growth opportunities.

If no new debt is issued to replace the retired portion of original debt, a sinking fund reduces asset substitution and both under- and overinvestment. It thereby increases firm value. Even if the retired debt is replaced, the sinking-fund payment schedule provides bondholders with the information

\footnotetext{
${ }^{13}$ Free cash flow is defined here as cash in excess of that required to invest in all projects with positive value and to maintain the firm's dividend level; see Jensen (1986).
} 
needed to assess future debt issues. It thus reduces creditors' search costs. Sinking funds benefit both high-growth and low-growth firms, and the benefits should be passed on to shareholders in the form of a lower interest rate on debt.

- The negative pledge. Debentures are unsecured claims against a firm's general assets. In case of default, debenture (bond) holders receive payment only after secured creditors have been paid. Although, as noted previously, much has been written recently about violations of the rule of absolute priority, virtually all studies have found that secured claims are honored in full under either Chapter 7 or Chapter 11 of the Bankruptcy Code. Thus, issuance of secured debt in the future vastly increases the risk and reduces the value of current bondholders' claims.

The negative pledge, by limiting the assets a firm can secure in the future, provides bondholders with some protection against increases in the risk of their claims. Marriott's $93 / 8$ percent debenture offered June 11, 1987, and due in 2007 contains a typical negative pledge:

Security. Not secured. Ranks on a parity with all other unsecured and unsubordinated indebtedness of Co. Co. will not, and will not permit any restricted subsidiary to create, assume or suffer to exist any mortgage, pledge, lien, deed of trust, security interest or similar encumbrance upon any of its or their property or assets, unless the offered debt securities shall be equally and ratably secured. This prohibition will not apply to: (a) any mortgage existing on March 1, 1985; (b) any mortgage on any property or assets of any restricted subsidiary to secure indebtedness owing by it to Co. or owing another wholly owned restricted subsidiary; (c) any mortgage on Co.'s headquarters facility in Bethesda, Maryland; (d) mortgages created to secure the purchase price of or indebtedness incurred to finance the construction cost of property acquired or constructed after Dec. 28, 1984, or mortgages existing on any such property at the time of acquisition, or any mortgage existing on any such property at the time of acquisition, or any mortgage existing on any property of any corporation at the time it becomes a restricted subsidiary, provided, however, that the aggregate principal amount of the indebtedness secured by all such mortgages on a particular parcel of property shall not exceed 100 percent of the fair market value thereof; (e) any refundings or extensions of any permitted mortgage for amounts not exceeding 100 percent of the fair market value of the property so secured and provided that such mortgage cover only the same property; (f) other mortgages in addition to the foregoing which secure indebtedness in an aggregate principal amount, which on the date such indebted- 
ness was incurred, did not exceed 10 percent of consolidated net tangible assets; and $(\mathrm{g})$ various other incidental liens.

Marriott's negative pledge is typical of most such covenants. First, it allows the firm to issue unlimited security as long as any current debt issue is "equally and ratably" secured. As long as the debentures are given secured status, their holders' risk does not increase. The covenant then excludes all assets already secured (at the time of debt issuance) and allows for specific exceptions. It allows any new assets purchased by the firm to be secured (clause $d$ ) and existing liens to be refunded. ${ }^{14}$ It also allows for a specified maximum level of secured assets in the future (in the Marriott example, 10 percent). Allowable percentages generally vary from zero to 20 percent, with a higher level affording less protection.

The Marriott negative pledge highlights another potential problem with recent debt issues. Although Marriott did not offer the debt until June 1987, it was shelf-registered under an indenture dated March 1, 1985. This practice is typical of shelf-registered debt. Some issuers update the indentures; most do not. 15

- Restrictions on sale and leaseback. By selling off general assets and leasing them back, the firm can erode the underlying general asset base that supports its debt level, thereby increasing the creditors' risk. Marriott's debt contains a typical sale/leaseback covenant:

Sale and leaseback. Neither Co. nor any restricted subsidiary may engage in any sale and leaseback transaction involving any hotel facility unless (a) Co. or such restricted subsidiary would be entitled to impose a mortgage on the hotel facility in question, or (b) within 240 days after the transaction, the net cash proceeds of the sale are applied to (i) the purchase or construction of properties, facilities or equipment, or (ii) the redemption of outstanding debt securities of any series, or (iii) the repayment of other indebtedness, or (iv) in part to such purchase or construction and in part to such redemption and/or such repayment.

\footnotetext{
${ }^{14}$ Securing new assets does not affect the original creditors' claims on the firm's general assets. They still have the same asset base as they had before (or a greater base, because not 100 percent of the assets' value will be secured).

${ }^{15}$ In the case of the negative pledge, the practice does no harm to creditor protection, because the assets referred to were already secured well before the issue. In the case of a dividend restriction, however, failure to update the indenture can result in a covenant so loose as to be totally ineffective; see the note about Pennzoil Company's dividend covenant in Table 9.
} 
Again, specific provisions vary among firms. In this case, Marriott is required either to reinvest the proceeds from the sale or to pay off this debt or another debt issue. Some firms do not allow such an alternative but prohibit any sale/leaseback that would not be allowed under the negative pledge.

- Limitations on distributions to owners. The dividend constraint actually limits all cash distributions to shareholders. Distribution (including share repurchase) may be made only when a positive dividend inventory of payable funds exists. The inventory is cumulative and includes all allowable earnings less dividends paid plus net new stock, including conversions, beginning on a specified day (usually prior to the debt issue). Most dividend covenants allow 100 percent of earnings to accumulate; a few limit accumulation to 50 percent or 75 percent of future earnings. In addition, the inventory includes a minimum dollar amount, called the dip, which is usually equal to one or more previous quarters' earnings. The tightness of the constraint is measured by the initial inventory accumulation date at issue and the size of the dip relative to previous earnings or dividends.

Charter Medical Corporation's 161/2 percent, 16 -year, sinking-fund debenture offered August 10,1982, contains such a provision:

Dividend restrictions. Co. will not (A) pay dividends or make distributions on its capital stock (other than in shares or stock rights or dividends on its outstanding series $A$, series $B$, series $C$ and series $D$ preferred stock), or purchase or redeem its stock or (B) make restricted investments or incur certain contingent liabilities, if the sum of (a) the amount expended for any such purpose; (b) all other amounts expended for such purposes in (A) commencing on October 1, 1981, through the date of the instant expenditure; and (c) the aggregate amount of restricted investments and such contingent liabilities outstanding at the end of such period would exceed the sum of (i) 50 percent of consolidated net income for the period commencing on October 1, 1981, and ending with a specified date within 90 days of the instant expenditure, (ii) the net proceeds received by $\mathrm{Co}$. during such period from the sale or issuance of its capital stock, other than to a subsidiary, for cash or tangible assets, or for capital stock or other securities of a person who simultaneously with such sale or issuance becomes a consolidated subsidiary, or upon certain conversions of indebtedness and (iii) $\$ 10,000,000$. In addition, certain purchases of minority interests in consolidated subsidiaries and certain stock redemptions in settlement of disputes are permitted. 
This dividend covenant is somewhat atypical, in that the 50 percent limit on allowable earnings is more restrictive than usual. ${ }^{16}$ Charter Medical had not paid Class A common dividends at the time of debt issuance, however. Therefore, as noted later, the covenant actually is much less restrictive than usual. The inventory begins to accumulate 10 months prior to issuance (that is, at the beginning of the company's fiscal year). The dip is $\$ 10$ million, representing approximately one year of earnings (1981 earnings were $\$ 11,570,000)$. In the year of issuance, Charter Medical paid $\$ 908,000$ in preferred stock dividends. The initial dividend inventory was thus approximately $\$ 14$ million and allowed for 15 years of dividends to be paid (at the current level) with no additions to the inventory.

Castle and Cooke Homes' $81 / 2$ percent debenture issued May 15, 1977, maturing in 1997, provides another example. Castle and Cooke's dividend restriction allowed 100 percent of additions to retained earnings. The inventory began accumulating on January 1,1977 , and the dip was $\$ 20$ million. Castle and Cooke earned $\$ 37$ million in 1976 and paid $\$ 13.6$ million in dividends. The company's initial inventory was approximately $\$ 38.5$ million $(9.5$ months of earnings) and allowed for 2.8 years of dividend payments without any increase in the inventory.

The dividend constraint is actually a minimum investment requirement (Kalay 1982). As such, it provides protection against underinvestment. Balancing the reduction in underinvestment, however, is the increased chance of overinvestment. Firms with many highly profitable, low-risk investment opportunities and relatively high financial leverage (prior to new debt issuance) should gain more from reducing underinvestment than they would lose from potential overinvestment. Mature firms, however, with relatively low leverage and with few "good" investment opportunities, are likely to generate excess free cash flow, which with minimum investment requirements, might have to be invested in negative-valued projects. ${ }^{17}$ Both owners and potential creditors of firms with many growth opportunities should benefit from restricted-distribution covenants, but firms and creditors with high levels of free cash flow would not.

Watts and Zimmerman (1986) argued that a limitation on distributions is ineffective. They suggested that, because the dividend constraint is based on

\footnotetext{
16 The tightness of initial restrictions is examined later in the study.

${ }^{17}$ Although firms with free cash flow that have a limitation on distributions to shareholders could use their excess cash to retire debt, the bonds might not be redeemed because of adverse incentives relating to conflicts between owners and managers. If they are not, then overinvestment results.
} 
accounting numbers (over which management has some control), as the inventory of payable funds decreases, management has incentives to change accounting rules (in accordance with generally accepted accounting principles) to increase reportable income and the dividend inventory. Healy and Palepu (1990) tested this proposition and found, however, that managers do not change accounting rules; rather, they cut dividends. This finding suggests that dividend restrictions work as intended.

- Limitations on debt. Among the most common debt covenants are those limiting future debt financing. A covenant can be written to control either the total consolidated amount of funded debt or only the amount of consolidated senior funded debt that can be issued in the future. The main goal is to limit a systematic increase in the riskiness of existing debt over time.

Firms with a limitation on debt are required to retire (repurchase) debt before engaging in new, highly levered transactions. Asquith and Wizman (1990) identified a limitation on debt as the most direct way to protect debtholders. They found that bondholders of firms going private through a leveraged buyout did not lose if they were protected by a limitation on debt. Creditors not so protected (even those protected by a negative pledge) lost value.

A limitation on debt generally establishes a minimum ratio of consolidated net tangible assets (CNTA) to the book value of long-term (funded) debt. For a given ratio, the greater the proportion of firm intangible assets and the higher the firm's financial leverage, the more restrictive the debt limitation. Note also that the firm may issue as much short-term debt as it wishes, because funded debt is equal to total assets minus short-term debt and equity. Short-term debt can be excluded because debt that matures before investment decisions have to be made cannot lead to risk shifting (asset substitution) or underinvestment. Charter Medical's indenture contains a typical limitation on debt:

Creation of additional debt. Co. will not incur or assume funded debt unless, after giving effect thereto, consolidated tangible net assets shall not be less than 1.35 times consolidated funded debt. However, funded debt may be extended, renewed or refunded so long as the total funded debt is not increased thereby.

Charter Medical's covenant (limiting debt to 74 percent of CNTA) is much less restrictive than the typical limitation on debt prior to 1980 . As will be seen shortly, the typical restriction limits debt to 50 percent of CNTA. Charter's covenant also limits all future debt, rather than just senior debt. Limitations that 
cover only senior debt may lead to large losses for debtholders under Chapter 11 filings, particularly because the courts routinely violate absolute priority.

Recent Innovations in the Debt Market. Since 1980, the debt market has experienced unprecedented innovation, including such new debt forms as zero-coupon bonds and original-issue-discount (OID) bonds. The two are similar. Zero-coupon bonds are issued at a price that reflects the discounted (at yield to maturity) value of the principal due at maturity. OID bonds carry coupon rates that are well below the current (at-issue) yield to maturity for bonds of the same risk. They are priced by discounting (at yield to maturity) both the interest payments and the principal due at maturity.

Both zero-coupon and OID bonds had distinct tax advantages initially, but the Internal Revenue Service quickly moved to have Congress close the tax loopholes. Some firms continued to issue OID debt, presumably because of the high level of interest rates. (A zero-coupon or OID bond, although having the same yield as a comparable interest-paying security, does not lock the firm into paying high semiannual coupons.) By late 1982, however, with the falling interest rates, most zero-coupon and OID corporate bonds had virtually disappeared.

The put, another innovation, was developed to protect creditors from rising interest rates. Analogous to the issuer's call protection, a put allows creditors to sell back their debt at par on a given date (or dates). As Wilson and Fabozzi (1990) noted, in periods of rising interest rates, issuers do not want to retire debt. Creditors can benefit, however, if they can sell back their debt and reinvest in higher rate securities. Puts generally allow redemption only within a short period (usually one month).

The Marriott 93/8 percent issue, offered in 1987 and maturing in 2007, contains a traditional put unrelated to event risk:

Repayment at the option of holder. The debentures will be repayable on June 15, 1997, at the option of the holders thereof, at 100 percent plus accrued interest to June 15, 1997.

Marriott's debentures may be put only on June 15, 1997. Holders must notify the company of a put within one month prior to the redemption date. Unfortunately for Marriott's creditors, the put will not become operational until almost four years after the division of the company.

- Event-risk covenants. The event-risk covenants that followed the RJR Nabisco LBO in 1988 took two basic forms--a so-called poison put and an interest rate reset. Both are triggered by specific events. The events vary but 
generally have to do with changes in corporate control. Most, but not all, event-risk covenants require that the triggering event be accompanied by a rating downgrade within a specified time period.

A poison put allows creditors to sell back their debt to the firm at par. It does not prohibit an event (usually a change in control) from taking place, but it increases the cost of the event by requiring repurchase of the bonds. Because a typical poison put does not take effect unless the board of directors opposes the change in control, it does not protect creditors against a highly levered but friendly takeover.

Coastal Corporation's indenture for a 101/4 percent senior debenture offered October 3, 1989, and due 2004 gives an example of a poison put:

Change in control. In the event a rating decline occurs within 60 days after a change in control occurs, the indenture will require $\mathrm{Co}$. to offer to purchase all of the debentures on or prior to the 90th day after the rating decline occurs at a price equal to 100 percent of the principal amount of the debentures plus accrued interest.

The Coastal event-risk put is triggered solely by a change in control accompanied by a ratings downgrade. The put operates throughout the life of the debenture. Why a change in control per se should cause creditor concern is difficult to understand, however. A more effective covenant would protect creditors in case of any ratings downgrade, as discussed in the section on credit-sensitive debt.

Harris Corporation's 103/8 percent debentures, offered on December 1, 1988 (one day after the RJR buyout), and due 2018 offers a less specific event-risk put than Coastal Corporation's:

Put right of debentureholders. In the event that (i) a designated event occurs on or before the tenth anniversary of the date of the indenture and (ii) on any date which occurs during the period commencing 90 days prior to the public disclosure of the occurrence of such designated event and ending 90 days after such public disclosure, the rating of the debentures is downgraded to lower than BBB - by Standard \& Poor's Corporation or lower than Baa3 by Moody's Investors Service, Inc., and, if such downgrading occurs prior to such public disclosure, the rating assigned to the debentures by S\&P or Moody's on the date of such public disclosure remains lower than $\mathrm{BBB}$ - or lower than Baa3, respectively, each holder of the debentures will have the right to put all or part of its debentures to $\mathrm{Co}$. for purchase price of 100 percent of the principal amount thereof, 
plus interest accrued to the date fixed for such purchase, which shall be 90 days from the date the Co. notifies the holders of the occurrence of the put event.

Under the terms of the Indenture, $\mathrm{Co}$. is obligated to give notice to debentureholders and the trustee within fifteen days following a put event specifying the date fixed for purchase of debentures by Co., the place at which debentures shall be presented and surrendered for purchase, that interest accrued to the purchase date will be paid upon such presentation and surrender and that interest will cease to accrue on such debentures to $\mathrm{Co}$. for purchase. A debentureholder to properly put its debentures to $\mathrm{Co}$. for purchase, a debentureholder must give notice and present and surrender its debentures to $\mathrm{Co}$. at the place specified in Co.'s aforementioned notice at least fifteen days prior to the purchase date. Any such put by a debentureholder shall be irrevocable. Co. is not obligated to purchase debentures or notify debentureholders with respect to more than one event.

The Harris put is triggered if (1) a person becomes a beneficial owner of 20 percent or more of the company's outstanding common stock or combined voting power, (2) the company consolidates with or merges into another corporation, or (3) the company or a subsidiary purchases, acquires, or distributes 30 percent of the company's capital stock within a 12 -month period ranging from 90 days before the public filing to 10 years after issuance of the debt. The covenant protects against toehold acquisitions by outsiders, mergers, and major share repurchases, whether the latter are designed for defensive purposes, to distribute proceeds from the sale of debt or assets to shareholders, or to take the company private. Again, why these actions (without an accompanying increase in credit risk) would constitute a potential problem for bondholders is difficult to understand.

The second type of event-risk covenant, the reset, allows bondholders to renegotiate the debt's coupon rate when the specified event occurs. United Technologies Corporation's 30-year, 87/8 percent debenture issued December 10,1986 , contains the following covenant requiring negotiation of interest rates:

Interest adjustment. In the event there occurs both (a) a designated event and (b) within the evaluation period, a rating decline, then the applicable rate payable on the debentures will be adjusted upward. In the event that, after an adjustment in the applicable rate, there occurs a subsequent rating increase, then the applicable rate payable on the debentures will be adjusted downward. 
The events that would trigger an interest rate adjustment are similar to those covered in the indenture discussed previously. Note that United Technologies can reduce the interest rate if the bonds are subsequently upgraded to their previous level.

Why are such covenants necessary? If creditors merely want protection against share repurchases, a dividend restriction would accomplish the purpose. If shareholders are concerned about mergers, they need only insert a covenant limiting mergers and requiring that debt be equally and ratably secured. ${ }^{18}$ If, as seems most probable, the creditors are concerned about highly levered transactions, limiting the total amount of debt the firm can issue would be a considerably more straightforward solution than an event-risk covenant. A covenant of the type offered by Coastal, Harris, or United Technologies fails to address the main concerns of creditors-change in control financed by debt. Creditors do not want the firm to engage in highly levered transactions or to engage in risk shifting.

Consider again the Marriott example. Although Marriott's indenture did not contain an event-risk covenant (the debt was issued one year prior to the RJR LBO), such a covenant would not have protected debtholders against the spin-off of Host Marriott and its assumption of the firm's debt. At best, an event-risk covenant can protect against only the last attempt at expropriation, not against heretofore unthought-of actions.

- Credit-sensitive debt. The credit-sensitive debenture is a recent innovation. The interest on credit-sensitive debt rises if the debt is downgraded for any reason; the change does not depend on a specific event. The relevant clause for Potlatch Corporation's 91/8 percent (initial), 20-year debentures offered on December 6, 1989, is worded as follows:

Interest. The interest rate payable on the debentures shall be based upon the debt rating on the debentures as determined by Standard \& Poor's or Moody's Investors Service, Inc., or their successors . . . and adjusted if necessary in response to changes in a rating.

A credit-sensitive issue avoids the problem of specification inherent in an event-risk covenant. It clearly protects creditors from almost any firm-specific event and thus reduces the risk in their claims. Its effect on the issuer, however, is less clear.

${ }^{18}$ Although equally and ratably securing debt does not make the debt senior to other debt, it does limit mergers. 
Credit-sensitive debt is similar to short-term debt. Firms have historically chosen to issue long-term debt, in part, to avoid the possibility of having to pay higher rates because of circumstances beyond their control. Credit-sensitive debt requires renegotiation every time the risk of the debt changes, whether that change results from the firm's actions or not. Since the advent of credit-sensitive debt, short-term rates have been consistently lower than long-term rates, however, so the advantage of issuing credit-sensitive debt is not obvious. Furthermore, such debt is still so new that the proper trade-off between issuer costs and creditor protection is not known.

If event-risk covenants are not the best way to provide protection, what methods do work? The next section reviews prior studies of the value and effectiveness of covenants.

Do Covenants Work? Brauer (1983) analyzed two debt offerings issued by Sunshine Mines in which the debt was identical in all respects except that one issue contained a dividend restriction and the other did not. Brauer found that the restricted issue yielded less and sold for more throughout the period of the study (December 1980 through March 1982). The market apparently values restrictions and is willing to pay for them. ${ }^{19}$

In a similar study, Roberts and Viscione (1984) examined whether security and/or seniority provisions are priced by the market. Their sample consisted of matched pairs of nonconvertible bonds issued by the same firm. The bonds had similar features except for seniority or security. Roberts and Viscione found that the market does price seniority/security (in the form of a lower yield). In addition, they found that bond ratings do not accurately reflect covenant protection.

Laber (1992) examined the covenants contained in two debt issues offered by J.P. Morgan's Northern Pacific Railroad (later Burlington Northern Railroad) in 1896. One issue was to mature in 1997, the other in 2047. The bonds contained no call and no sinking fund and allowed for no amendments. In addition, they contained a restriction on the sale of certain railroad lands and their mineral rights. For years, Burlington attempted to circumvent the restriction and call the debt. The courts consistently blocked these efforts. Finally, in 1987, Burlington reached an agreement with the remaining bondholders. At the time, $\$ 117.7$ million of debt was still outstanding, $\$ 69.9$ million

\footnotetext{
${ }^{19}$ Actually, the findings showed only that the market was willing to pay for restrictions during the study period. Whether potential bondholders are willing to trade yield for covenants in today's market is not known.
} 
of the first issue and $\$ 47.8$ million of the second. The settlement called for Burlington to pay $\$ 35.5$ million to bondholders and $\$ 3.4$ million to lawyers. The stock market reaction to the settlement was significantly positive.

Laber's study shows that, despite the view of some analysts (e.g., McDaniel 1988), covenants are effective and can be enforced. In fact, they are so effective that in the Burlington case, negating them through large payouts was considered good news by owners. Eastman and Viswanath (1992) have noted, however, that enforcement of a settlement may be less than optimal.

Warga and Welch's (1990) examination of bondholder losses in LBOs did not explicitly address covenant protection, but the authors noted that priority covenants are unlikely to be enforced. ${ }^{20}$ They did not uncover any systematic relationship between bondholder losses and shareholder gains. That is, although bondholders suffer large declines in wealth, the losses are not the result of wealth expropriation. Overall, Warga and Welch found that bondholder losses are less than shareholder gains, so firm value increases. Eastman and Viswanath (1992) suggested that such gains should not be precluded, because they are economically valuable.

Asquith and Wizman (1990) undertook the most complete study of the effect of covenants in protecting creditors. They investigated 214 bonds of 65 LBO targets during the period from 1980 to 1988. They classified each bond's protection level as weak or strong. All bonds that limited total funded debt or that had a net-worth restriction on the surviving firm in a merger were classified as having strong protection. Bonds that limited only senior funded debt or that restricted dividends or other distributions to shareholders were classified as having weak protection. ${ }^{21}$ Firms having none of these covenants were classified as having no protection. ${ }^{22}$ Of the 171 bonds with known covenants, 27 were classified as having strong protection, 64 as having weak protection, and 80 as having no protection. Of the 27 with strong protection, 21 included a limitation on debt. Asquith and Wizman examined the abnormal returns for all buyouts,

${ }^{20}$ Franks and Torous (1989) documented that deviations in absolute priority are the rule, not the exception. Also see Malitz and Cohn (1987).

${ }^{21}$ Although for the Asquith and Wizman (1990) study firms with a limitation on distribution to shareholders were correctly considered to have weak protection, creditors are not necessarily protected from other adverse (to creditor) actions. For example, a large share repurchase or dividend financed by the sale of assets can be extremely harmful to creditors if the firm is facing financial distress.

${ }^{22}$ Note that issues that contain a negative pledge and/or a restriction on sale/leaseback would be classified as no protection. Neither covenant is considered to provide much protection against specific event risk (rather than ordinary risk). 
whether successful or not. They found positive abnormal returns to bonds with strong protection and negative returns to those with weak or no protection.

Focusing only on successful bids, Asquith and Wizman found even more striking results. Of the 14 bonds classified as having strong protection, only 4 were still outstanding after the buyout. Their restrictions required retirement of the debt, whether by call, tender offer, or defeasance. Of the 4 bonds that remained outstanding, the covenants of 2 were not violated (the buyout did not use enough debt). Only Wickes Companies, with 2 bonds outstanding, managed to avoid repurchasing the debt. Wickes established a new holding company, WCI, which acquired the original company as a subsidiary and issued new debt at the parent level. ${ }^{23}$

Asquith and Wizman also reported on the decreased use of traditional covenants after 1980 . They noted that, prior to 1980,83 percent of investmentgrade debt contained both the dividend and debt covenants, but in the 1980-88 period, only 22 percent were restricted. At the same time, the rating firms were paying more attention to specific event-risk covenants. In 1989, Standard $\&$ Poor's began reporting unique event-risk protection. It now describes and rates separately each new bond's specific event-risk protection. Moody's does not publish separate event-risk ratings, but it states that such covenants are taken into consideration when rating the debt.

Standard covenant protection (limitations on debt and dividends) has always been a part of the rating process (see Wilson and Fabozzi 1990). Because existing covenants provide strong protection, Asquith and Wizman questioned the need for explicit event-risk covenants. They concluded that the simultaneous reduction in traditional protection and introduction of new protection constituted an anomaly.

The Asquith and Wizman study was confined to those firms that were targeted for a leveraged buyout. It included all public debt issues, regardless of maturity, security, or seniority. To compare the use of covenants over time, however, the underlying features of the issues must be standardized. One cannot compare short-term debt with long-term debt (consider the sinking fund, for example), unsecured debt with secured debt (which holds claim to a specific asset), or debt of various seniorities (which, although seniority is not strictly observed, does get some consideration from the courts). The present study, therefore, examines a subset of debt offerings classified as long-term (at least

\footnotetext{
${ }^{23}$ On January 31, 1990, WCI was bought by Collins and Aikman, and $\$ 585$ million in debt was retired through repurchase. Thus, the bondholders were not harmed by the original LBO. In July 1992, WCI was renamed Collins and Aikman.
} 
15 years), senior debentures issued by industrial or retail firms. The empirical portion of the study draws heavily on Malitz (1986) by using that study's sample of 252 long-term debentures issued between 1960 and mid-1980 and updating the data through 1991 .

\section{Empirical Evidence: The Incidence of Bond Covenants}

The study sample was selected from all long-term debt issued between 1960 and 1991. To ensure comparability of issues through time, the following criteria were applied: 24

1. The debt had to be issued by a firm classified by Moody's as an industrial.

2. Bond issues were limited to unsecured, senior, nonconvertible debentures with at least a 15-year maturity.

3. The debt had to be issued by a company whose stock is publicly traded, and trading data had to be available for a three-year period prior to issuance of the debt.

4. The restrictions in the selected debentures had to be at least as binding as those of any long-term debt previously issued by the firm and still outstanding. 25

5. The use of more than one debt issue for the same firm was limited as follows:

- If the restrictions on each issue were identical, issues separated by at least ten years were used in the sample.

- If a later issue contained more binding, or different, restrictions than an earlier issue, both issues were used, regardless of the dates of issuance.

- When the restrictions on a later issue were less binding, the later issue was eliminated and only the earlier, most restrictive issue was used.

The initial sample of candidate debentures was selected from Moody's Bond Survey by applying criteria 1 through 3. Moody's Industrial Manual was then used to apply criteria 4 and 5 .

\footnotetext{
24 The original sample required a call provision, deferred for a period of between five and ten years. For the period from 1960 through mid-1980, this requirement eliminated only two firms. After 1980, many issues did not contain a deferred call. Thus, the criterion was eliminated from the sample selection process.

${ }^{25}$ Because short-term restrictions expire within one year, they are not reliable as protection for holders of long-term debt. The one exception is revolving-credit agreements, which are treated as long-term restrictions for the purpose of sample selection.
} 
Application of the selection criteria resulted in a sample of 414 debentures issued by 269 separate firms. Of the sample issues, 252 debentures were in the original sample; 162 issues were added. Between 1960 and 1979, 243 debentures were issued by 220 firms. Between 1980 and March 1991, 144 debentures were issued by 132 firms. An additional 27 debentures were issued by 27 firms between April 1991 and March 1992. ${ }^{26}$ The sample was classified according to covenant sets: debentures with no covenants; debentures with no sinking fund but with a dividend restriction, debt restriction, put covenant, credit sensitivity, or some combination; debentures with a sinking-fund requirement only; debentures with a sinking-fund and one other covenant; and debentures with a sinking fund and restrictions on dividends and debt. ${ }^{27}$

Characteristics of the Sample. Issue-related data were gathered from various sources, including each debenture prospectus, Moody's Bond Survey, and Moody's Industrial Manual.

- The debentures. Table 3 presents the year of issuance of each of the sample debentures. The debentures are evenly distributed through time; 95 debentures (23 percent) were offered in the $1960 \mathrm{~s}, 148$ (35.7 percent) were offered in the 1970s, and 171 (41.3 percent) were issued after 1979-136 (32.9 percent) in the 1980s and 35 (8.4 percent) from 1990 through March 1992.

Debt issues flow in cycles. During periods of high interest rates, such as in the late 1970 s and early 1980 s, little debt is issued; when interest rates are relatively low, firms issue more debt. ${ }^{28}$ The dramatic decline in rates in 1982 , for example, triggered the largest debt market in history. Peak periods of debt issuance were 1967, 1970-72, 1974-77, 1980-82, 1985-87, and 1991-92.

\footnotetext{
${ }^{26}$ The number of issuing firms in the two time periods do not add to the total because many firms issued debentures in both the early and later periods. Seventy-three firms issued two debentures, 22 firms issued three, and 2 firms issued four. The 27 debentures offered after March 1991 are mentioned separately because of data problems. The debentures are included in the analysis of the issues and covenants, but because neither Compustat nor Moody's Industrial Manual is available beyond early 1991, firm-specific descriptive data were not available. Therefore, some results are presented for the full 414-issue sample but other results show characteristics only for the 387 debentures offered prior to April 1991. Firm-specific data were available for 2 of the 21 debentures issued in 1991.

${ }^{27} \mathrm{~A}$ list of the issuing firms, the years of issuance, and the Moody's bond ratings at issuance for each debenture, grouped by types of covenants, is available from the author upon request.

${ }^{28}$ Of course, the interest rate is not the sole determinant of debt issuance. The state of the stock market is also important: When the stock market declines, firms are likely to choose debt rather than equity financing.
} 


\section{TABLE 3. Distribution of 414 Long-Term Debentures Issued between January 1960 and March 1992 by Year of Issuance}

\begin{tabular}{|c|c|c|}
\hline Year & Number & Percent \\
\hline 1960 & 9 & 2.2 \\
\hline 1961 & 10 & 2.4 \\
\hline 1962 & 4 & 1.0 \\
\hline 1963 & 7 & 1.7 \\
\hline 1964 & 2 & 0.5 \\
\hline 1965 & 7 & 1.7 \\
\hline 1966 & 10 & 2.4 \\
\hline 1967 & 30 & 7.2 \\
\hline 1968 & 7 & 1.7 \\
\hline 1969 & 9 & 2.2 \\
\hline 1970 & 30 & 7.2 \\
\hline 1971 & 30 & 7.2 \\
\hline 1972 & 15 & 3.6 \\
\hline 1973 & 7 & 1.7 \\
\hline 1974 & 14 & 3.4 \\
\hline 1975 & 15 & 3.6 \\
\hline 1976 & 15 & 3.6 \\
\hline 1977 & 10 & 2.4 \\
\hline 1978 & 6 & 1.5 \\
\hline 1979 & 6 & 1.5 \\
\hline 1980 & 17 & 4.1 \\
\hline 1981 & 11 & 2.7 \\
\hline 1982 & 14 & 3.4 \\
\hline 1983 & 5 & 1.2 \\
\hline 1984 & 4 & 1.0 \\
\hline 1985 & 18 & 4.4 \\
\hline 1986 & 38 & 9.2 \\
\hline 1987 & 15 & 3.6 \\
\hline 1988 & 6 & 1.4 \\
\hline 1989 & 8 & 1.9 \\
\hline 1990 & 6 & 1.4 \\
\hline 1991 & 21 & 5.1 \\
\hline 1992 & 8 & 1.9 \\
\hline
\end{tabular}


Almost one-quarter of the sample debentures were issued during the last two periods.

The rebound in the debt market after the RJR Nabisco LBO in 1988 is interesting. In 1989 and 1990, little debt of any kind was issued, but during the period beginning April 1991 and ending March 1992, 67 long-term, senior debentures were issued (only 27 of these issues qualified for inclusion in the sample). The explanation is not clear; interest rates were low during the later period, but they were also low between 1989 and 1990. The junk bond market, which rebounded fully after its low following the RJR Nabisco LBO, also peaked in the 1991-92 period.

Issues can be classified by maturity, rating, purpose, and type. Table 4 presents these characteristics. Most of the issues (84 percent) were to mature either 25 or 30 years from issuance. The majority were medium grade; more than 69 percent carried a Moody's rating at issuance of A or Baa. About 27 percent were high-grade (Aaa or Aa) bonds, and only a little more than 3 percent were less than investment grade or unrated. ${ }^{29}$

More than half of the debentures were issued to repay debt (37 percent to repay short-term debt and 15 percent to refund long-term debt). An additional 21 percent were issued for investment purposes (including merger, acquisition, share repurchase, and other forms of liability restructuring). About 26 percent were issued for general purposes.

The bulk of the issues were not shelf registrations. This characteristic is not surprising, because SEC Rule 415 did not take effect until March 5, 1982. ${ }^{30}$ Since that time, 105 of the 141 debentures issued have been shelf registrations. Although in the early years of shelf registration, only about half of the issues were shelf-registered, by 1986 the majority were, and in the last year of the sample, 25 of the 27 debentures were shelf registrations. The use of shelf registration is becoming the norm.

The vast majority (nearly 96 percent) of the issues are straight coupon debentures. A small number are original-issue discounts (prior to 1983), serial or adjustable-rate bonds, or debt guaranteed by a parent company.

The quality of the offering underwriters is important because it may affect

\footnotetext{
${ }^{29}$ The study covers a period in which the junk bond market was exploding, but most junk issues were (and are) for quite short terms, ten years or less. Therefore, they are not a part of the sample.

${ }^{30} \mathrm{SEC}$ Rule 415 allows companies with more than $\$ 150$ million of outside stock to register the total amount of securities they plan to issue during the next two years. Because shelf registration increases managerial flexibility, most firms that are eligible to shelf-register do so.
} 
TABLE 4. Characteristics of 414 Long-Term Debentures Issued 1960-92

\begin{tabular}{lrr}
\hline Characteristic & Number & Percent \\
\hline Years to maturity at issuance & & \\
$15-18$ & 11 & 2.7 \\
20 & 52 & 12.5 \\
25 & 193 & 46.6 \\
30 & 156 & 37.7 \\
40 & 2 & 0.5 \\
Rating at issuance & & \\
Aaa & 23 & 5.6 \\
Aa & 89 & 21.5 \\
A & 208 & 50.2 \\
Baa & 80 & 19.3 \\
Ba & 1 & 0.2 \\
B & 7 & 1.7 \\
Unrated & 6 & 1.5 \\
Purpose of issue & & \\
Repay short-term debt & 155 & 37.4 \\
Repay long-term debt & 61 & 14.7 \\
Investment & 86 & 20.7 \\
General purposes & 107 & 25.8 \\
No purpose given & 5 & 1.2 \\
Shelf registration & 105 & 25.4 \\
Type of issue & & \\
Coupon & 11 & 95.4 \\
OID & 595 & 2.7 \\
Serial (includes amortizing) & 1 & 1.2 \\
Adjustable rate & & 0.2 \\
Guaranteed & 0.5 \\
\hline
\end{tabular}

both the marketability and the risk of the issue. Hayes (1971) suggested that a definite hierarchy exists in the investment banking industry. Carter and Manaster (1990), studied this hierarchy by examining tombstone announcements in the Investment Dealer's Digest from 1979 through 1983. In a tombstone, the lead underwriter is listed at the top to the left, and the co-lead is listed on the top right. Other underwriters in the syndicate are listed below in order of importance. Carter and Manaster developed a ranking scale based on assigning an integer rank to each underwriter according to its position. The result was a measure of underwriter reputation on a scale from zero (least 


\section{TABLE 5. Underwriter Prestige for 410 Long-Term Debentures Issued 1960-92}

\begin{tabular}{lrr}
\hline Underwriter & Number & Percent \\
\hline & & \\
Prestige rating of 9 & 256 & 62.5 \\
First Boston Corp. & 48 & 11.7 \\
Goldman, Sachs \& Co. & 91 & 22.2 \\
Merrill Lynch White Weld & 49 & 12.0 \\
Morgan Stanley \& Co. & 43 & 10.5 \\
Salomon Brothers & 25 & 6.1 \\
Prestige rating of 8 & 132 & 32.1 \\
Bache Halsey Stuart and Shields & 2 & 0.5 \\
Bear, Stearns \& Co. & 3 & 0.7 \\
Blyth Eastman Dillon Read & 26 & 6.3 \\
Dean Witter Reynolds & 3 & 0.7 \\
E.F. Hutton & 3 & 0.7 \\
Kidder, Peabody \& Co. & 9 & 2.2 \\
Lazard Frères \& Co. & 9 & 2.2 \\
PaineWebber & 3 & 0.7 \\
Shearson Lehman Bros. (Kuhn Loeb) & 42 & 10.3 \\
Smith Barney & 31 & 7.6 \\
Wertheim \& Co. & 1 & 0.2 \\
Medium-to-low prestige rating (less than 8) & 22 & 5.4 \\
Drexel Burnham Lambert (7) & 11 & 2.8 \\
Loeb Rhoades Shearson (7) & 2 & 0.5 \\
Robert Baird (6.5) & 1 & 0.2 \\
Shearson Hayden and Stone (6) & 1 & 0.2 \\
Allen \& Co. (5) & 1 & 0.2 \\
Ohio Co. (5) & 1 & 0.2 \\
Unrated & 5 & 1.2
\end{tabular}

Note: Four firms did not report a lead underwriter and were excluded.

The five unrated underwriters were Dominick \& Dominick, Glore Foregan, F.I. DuPont, Harrison Ripley, and J.P. Morgan Securities.

prestigious) to nine (most prestigious). Firms ranked nine were never dominated by other firms and are clearly the most prestigious. Five firms-First Boston, Goldman, Sachs, Merrill Lynch, Morgan Stanley, and Salomon Brothers-were ranked nine.

Table 5 lists the underwriters associated with this monograph's study by quality (prestige) rating and the number of sample debentures offered by each. The sample contains issues up to 18 years before and 9 years after the Carter 
and Manaster study period. During the entire 32-year period, many underwriters disappeared or merged. In five cases in which neither the original underwriter nor a surviving company could be identified, the underwriter was assigned a rank of zero.

The most prestigious underwriters issued 256 (62.5 percent) of the debentures in the study. The next most prestigious underwriters offered an additional 132 ( 32.1 percent). The remaining 22 issues (5.4 percent) were offered by lower prestige or unrated underwriters.

Overall, the majority of the debentures were long-term, highly rated (low-default-risk) issues marketed by the most prestigious underwriters.

- Issuing firms. Table 6 describes characteristics of the issuing firms. Data on asset value and the book value of long-term debt were taken from Compustat. The market value of equity was taken from the Center for Research in Security Prices (CRSP) data base. Total capital was measured as the market value of equity plus the book value of long-term (funded) debt. Issuing costs, computed as the price at issuance less the proceeds to the company as a percentage of total proceeds, were taken from Moody's Industrial Manual or the debenture prospectus. Because data for the 27 debentures offered between April 1991 and March 1992 were not available, those issues are not included in these tables.

Issuing firms were large, with a mean asset value of $\$ 3.41$ billion and a mean market value of equity of nearly $\$ 2.13$ billion. The median firm had $\$ 1.235$ billion in assets and equity worth $\$ 808$ million. Sizes of the sample debt issues range from $\$ 2$ million to $\$ 1$ billion, with an average of $\$ 110.64$ million. As a percentage of previous total capital, issue values range from 1 percent to 64 percent, averaging 9 percent. The median firm had $\$ 137.18$ million in debt prior to the sample offering, which added $\$ 75$ million in new debt. As a percentage of total long-term debt (including the sample issue), the sample issues range from 4 percent to 100 percent, averaging 38 percent. The new debt raised the median sample's leverage from 19 percent to 27 percent. Before issuing the sample debt, the average firm's leverage was slightly below the industry average; after issuance, its leverage was slightly above the industry average.

Issuing costs averaged 1.02 percent and range from 0.22 percent to 3.9 percent of proceeds to the firm. The relatively low costs reflect the high quality of the issuing firms and the issues.

Table 7 reports statistics on firm profitability, fixed assets (assets in place), growth potential, and risk -all of which are thought to affect debt quality. Profitability, for example, indicates a firm's ability to pay interest and sinkingfund charges. It is measured in two ways-as earnings before interest and taxes as a proportion of total assets, and as cash flow (earnings before depreciation, 


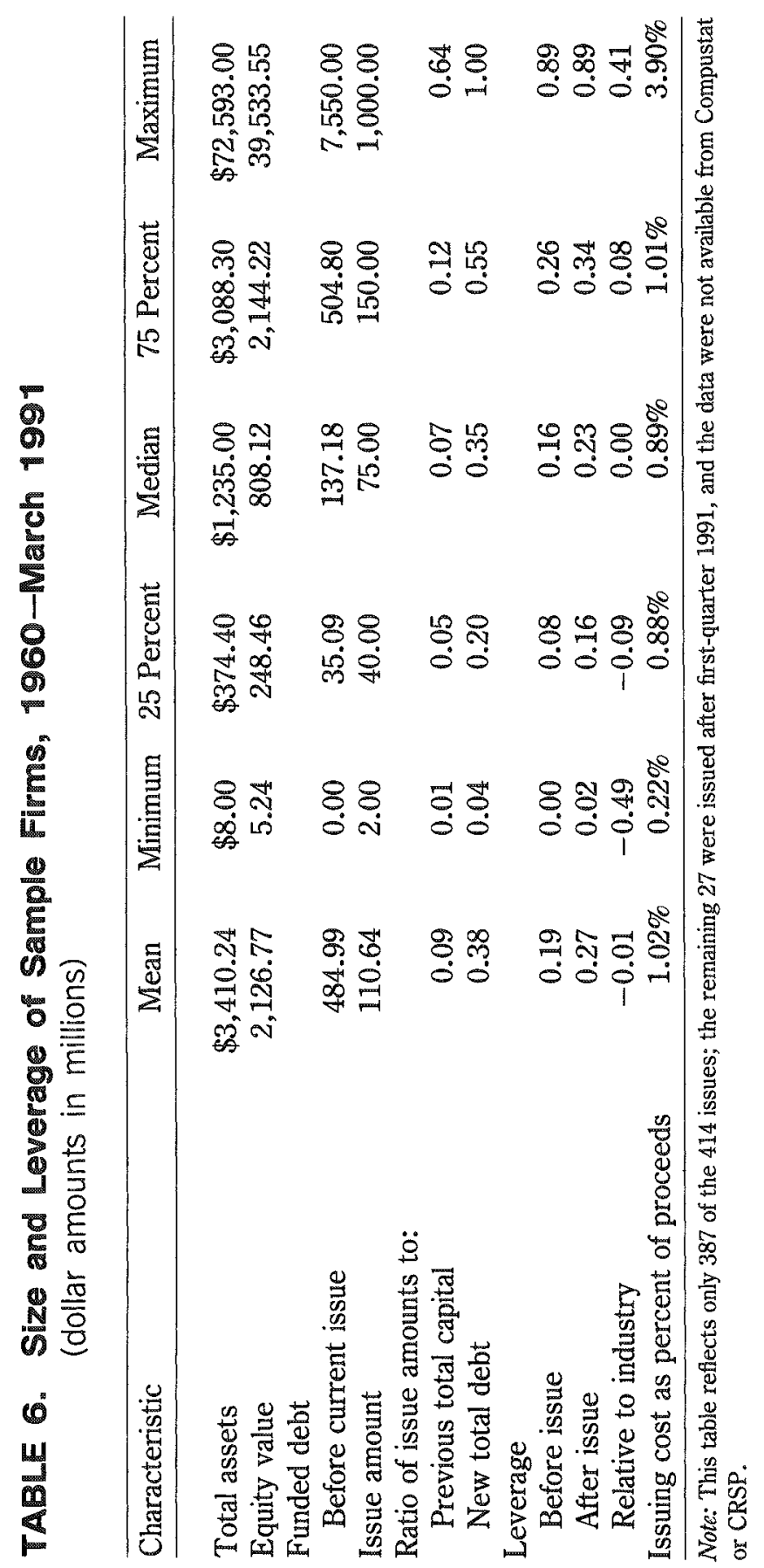




\section{TABLE 7. Profitability, Risk, and Growth of Issuing Firms, 1960-March 1991}

25

75

Characteristic

Mean Minimum Percent Median Percent Maximum

\begin{tabular}{|c|c|c|c|c|c|c|}
\hline Earnings profitability & 0.13 & 0.02 & 0.10 & 0.13 & 0.16 & 0.39 \\
\hline Cash flow profitability & 0.17 & 0.03 & 0.14 & 0.17 & 0.20 & 0.41 \\
\hline Ratio of net fixed to total & & & & & & \\
\hline $\begin{array}{l}\text { assets } \\
\text { Growth ratio (market value }\end{array}$ & 0.42 & 0.05 & 0.30 & 0.39 & 0.53 & 0.83 \\
\hline to book value of equity) & 1.83 & 0.36 & 0.99 & 1.50 & 2.26 & 12.73 \\
\hline $\begin{array}{l}\text { Risk (standard deviation of } \\
\text { stock returns) }\end{array}$ & 0.08 & 0.03 & 0.06 & 0.08 & 0.09 & 0.2 \\
\hline Risk relative to market & 0.97 & -0.09 & 0.54 & 0.91 & 1.23 & 3.90 \\
\hline
\end{tabular}

Note: This table reflects only 387 of the 414 issues.

interest, and taxes) as a proportion of total assets. Both measures are averaged over the three years preceding issuance of the sample debt.

Relatively recent investments in fixed assets suggest that a firm is maintaining and replacing assets as necessary and is not underinvesting. Thus, firms with high net fixed assets (low accumulated depreciation) as a percentage of total assets should require relatively fewer restricting covenants.

Kalay (1982) identified firm growth as a signal of the need for a dividend restriction in the debt indenture, because high-growth firms have more opportunities to underinvest than firms with low growth. Growth in Table 7 is measured as the market value of equity relative to a firm's book value of equity. The ratio presumably indicates the firm's capitalized future growth opportunities. The higher a firm's growth ratio, the more profitable the firm should be in the future. Although current profitability depends on assets in place, and future profitability depends on growth, the two characteristics are likely to be highly correlated.

Finally, firm risk is proxied by the standard deviation of the firm's monthly stock returns for the preceding 60 months, measured both independently and relative to the NYSE market index during the same period.

Table 7 reveals that the average firm had earning power (earnings profitability) equal to 13 percent of its total assets and cash flow profitability of 17 percent. Fixed assets net of depreciation expense as a percentage of total assets range from 5 percent to 83 percent, averaging 42 percent. The average firm's growth ratio was 1.83; that is, its market value of equity was 83 percent greater than its book value of equity. The risk of the average firm as measured 
TABLE 8. Incidence of Covenants in 414 Long-Term Debentures, 1960-92

\begin{tabular}{|c|c|c|}
\hline Covenant & Number & Percent \\
\hline Call & 366 & 88.4 \\
\hline Not deferred & 12 & 2.9 \\
\hline Deferred $1-4$ years & 7 & 1.7 \\
\hline Deferred 5 years & 47 & 11.4 \\
\hline Deferred 6-9 years & 6 & 1.4 \\
\hline Deferred 10 years & 291 & 70.3 \\
\hline Deferred 20 years & 3 & 0.7 \\
\hline No call & 48 & 11.6 \\
\hline Sinking fund & 344 & 83.1 \\
\hline Negative pledge & 383 & 92.5 \\
\hline Sale/leaseback & 336 & 82.1 \\
\hline Limitation on distributions to owners (dividends) & 145 & 35.0 \\
\hline Limitation on funded debt & 137 & 33.1 \\
\hline Limitation on senior debt only & 52 & 12.6 \\
\hline Limitation on all funded debt only & 52 & 12.6 \\
\hline Limitation on senior and all funded debt & 33 & 7.9 \\
\hline Limitation on mergers $^{\mathrm{a}}$ & 28 & 6.8 \\
\hline Limitation on transfers of assets ${ }^{a}$ & 11 & 2.7 \\
\hline Deferred put & 8 & 1.9 \\
\hline Event-risk put & 8 & 1.9 \\
\hline Event-risk interest change & 1 & 0.2 \\
\hline Credit-sensitive debt & 2 & 0.5 \\
\hline
\end{tabular}

'Moody's Industrial Manual does not accurately report limitations on mergers and transfers of assets. Therefore, information about these covenants is provided solely to indicate their relative inclusion in debentures.

by standard deviation was 0.08 percent, representing 97 percent of the variation of the market.

The issuing firms were representative of all large firms in the sample period. They were profitable and had high levels of assets in place, lower-than-average risk, and substantial growth potential.

Description and Incidence of Bond Covenants. Table 8 presents the frequency of each covenant contained in the 414 sample debentures. The most frequently offered covenant was a call provision, but the call provisions varied widely in specifics. The majority (83 percent) prohibited a call for 
refunding for a period of between five and ten years. ${ }^{31}$ Of the 48 debentures that did not include calls, 38 percent were issued after 1988. Of the 414 sample debentures, 344 ( 83 percent) contained a sinking fund. Of the 70 issues without a sinking-fund provision, 43 were issued after 1988 and the remainder were issued between 1980 and 1987. The typical sinking fund was deferred for between five and ten years after issuance and retired 88.5 percent of the issue prior to maturity. None of the issues without a call provision contained a sinking fund, nor did 22 of the callable issues.

The results reported here differ somewhat from those in Mitchell (1991). Studying 115 long-term (15 or more years to maturity) debt issues offered between 1982 and 1986, Mitchell found that 104 (90 percent) contained both a call and a sinking-fund provision. Only 8 had no call or sinking-fund provision. The present sample has a higher proportion of noncallable debt than Mitchell's sample, but most of it was issued after 1988, outside Mitchell's sample period. The major difference between the two samples is the number of callable issues without sinking funds. Mitchell found only 2 such issues (1.7 percent); 25 callable issues in the present study ( 6 percent) did not contain a sinking fund. Of the 79 debentures issued in her sample period (1982 through 1986), 7 (8.9 percent) were callable but had no sinking fund.

Some form of negative pledge was present in 92.5 percent of the issues studied. The typical negative pledge allowed some additional secured debt (between 5 and 20 percent).

A limitation on distributions to owners (dividend constraint) was found in 145 (35 percent) of the issues. Of the 137 issues (33 percent) that restricted future debt, 33 restricted both senior and all funded debt, 52 restricted senior debt only and 52 restricted all funded debt. A limitation on mergers was found in 28 (7 percent) of the issues, and 11 (3 percent) restricted the transfer of assets. ${ }^{32}$ Some type of put, either deferred or related to event risk, was found in 16 of the debentures (4 percent). Finally, 1 debenture contained an interest rate trigger, and 2 issues were credit sensitive.

Table 9 presents some data on the tightness of the limitations on distributions to owners. The tightest restriction called for the dividend inventory of

${ }^{31}$ All the issues that deferred the call did so for refunding purposes (a two-tiered call). In Thatcher's (1985) sample, one-third of the issues had a regular call. Her sample contained many short-term debt issues, however, and the term to maturity was a major determinant.

${ }^{32}$ Asquith and Wizman (1990) correctly noted that Moody's does not always indicate the presence of a limitation on mergers. Thus, the likelihood is that many more firms than reported restricted mergers. 


\section{TABLE 9. Terms of the Limitations on Distributions to Shareholders: 140 Firms, 1960-92}

\begin{tabular}{lrrrr}
\hline Characteristic & Mean & Median & Minimum & Maximum \\
\hline Months of earnings in initial & & & & \\
$\quad$ inventory & 7.10 & 5.00 & 0.00 & $174.00^{\mathrm{a}}$ \\
Percentage of retained earnings & $98 \%$ & $100 \%$ & $50 \%$ & $100 \%$ \\
Dip (\$millions) & 29.10 & 19.50 & 0.00 & 300.00 \\
Years of earnings available & 1.44 & 1.35 & $-3.19^{\mathrm{b}}$ & 5.04 \\
Years of dividend payments & 4.56 & 3.61 & 0.93 & 26.62 \\
\hline
\end{tabular}

Note: Dividend restrictions characterize 145 issues. Of those, five restrictions are nonstandard and terms could not be computed.

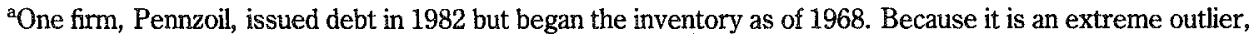
it biases the number of months of the initial inventory. Thus, the median is a more accurate measure of tightness than the mean.

${ }^{b}$ One firm had negative earnings in the year prior to debt issuance.

payable funds to begin accumulating on the day of debt issuance. The loosest allowed 174 months of accumulation prior to debt issuance. ${ }^{33}$ All but three covenants allowed 100 percent of earnings (less dividends paid) to be added to the inventory of payable funds. The dip ranged from zero (no dip) to $\$ 300$ million and averaged $\$ 29$ million.

The average size of initial inventory as a percentage of the average earnings in the three most recent years (deflated for price-level changes) resulted in 1.44 years of earnings available for distribution to shareholders. A more relevant measure is initial inventory as a proportion of current (at the time of debt issuance) dividends. This measure indicates the number of years a firm can continue paying dividends at the current level. Initial inventories in the sample allowed for between 1 and 27 years of dividend payments. The average restriction allowed almost 5 years of payments. Thus, in most cases, restrictions took into account variations in the business cycle. Firms could continue to maintain (or even increase) dividends even during short periods of negative earnings; only after prolonged losses would dividends need to be cut.

The terms of the limitations on debt differ among issues and firms. Table 10 presents some data on the limitations placed on future senior and total debt. Of the 79 firms whose indentures had a standard limitation on all consolidated

\footnotetext{
${ }^{33}$ Only one firm had this loose restriction; for all others, the initial dividend-inventory figures
} range from zero to 15 months prior to issuance, averaging 5 months. 


\section{TABLE 10. Terms of the Limitations on Future Debt: 130 Issues, 1960-92}

\begin{tabular}{lcrr}
\hline Assets/Debt & Debt/Assets & Number & Percentage of Firms \\
\hline CNTA/CFD & & & \\
1.35 & & 2 & 2.5 \\
1.50 & $74.1 \%$ & 1 & 1.3 \\
1.75 & 66.7 & 3 & 3.8 \\
1.85 & 57.1 & 1 & 1.3 \\
2.00 & 54.1 & 43 & 54.4 \\
2.25 & 50.0 & 8 & 10.1 \\
2.33 & 44.4 & 2 & 2.5 \\
2.50 & 42.9 & 15 & 19.9 \\
2.75 & 40.0 & 1 & 1.3 \\
3.00 & 36.4 & 3 & 3.8 \\
& 33.3 & & \\
CNTA/CSFD & & & \\
1.60 & & 1 & 1.25 \\
1.75 & 62.5 & 1 & 1.25 \\
2.00 & 57.1 & 37 & 46.25 \\
2.25 & 50.0 & 15 & 18.75 \\
2.50 & 44.4 & 26 & 32.50 \\
\hline
\end{tabular}

Note: Based on 129 issues that contained a standard limitation on debt. Thirty-two firms limited both senior and total funded debt, 48 limited total debt only, and 49 limited only senior debt.

${ }^{\mathrm{a}} \mathrm{CNTA}=$ consolidated net tangible assets, $\mathrm{CFD}=$ consolidated future funded debt, and $\mathrm{CSFD}=$ consolidated senior funded debt.

future funded debt (CFD), ${ }^{34}$ the limitation level varied from 1.35 to 3.00 times consolidated net tangible assets. The inverse of this ratio-CFD to CNTA-is also reported. Of the 79 firms, 7 covenants (8.9 percent) restricted funded debt to less than 54 percent of CNTA. The majority (55 percent) restricted debt to 50 percent of CNTA. Another 25 covenants (32 percent) allowed debt of $40-50$ percent of CNTA. The remaining 4 covenants (5 percent) allowed debt of less than 33 percent of tangible assets. Given the debt limits and current levels of funded debt, the average firm could issue future debt amounting to 23.5 percent of its tangible assets. Clearly, the limitation on all funded debt would preclude most highly levered transactions.

Table 9 also shows the allowable limits on consolidated senior funded debt

${ }^{34}$ A nonstandard limitation is one that does not limit CFD to CNTA. 


\section{TABLE 11. Covenant Sets in 414 Debentures, 1960-92}

\begin{tabular}{lrr}
\hline Covenant Set & Number & Percent \\
\hline No covenants & 50 & 12.1 \\
Sinking fund only & 191 & 46.2 \\
Other covenant only $^{\mathrm{a}}$ & 18 & 4.3 \\
Other covenant and sinking fund $^{\mathrm{a}}$ & 2 & 0.5 \\
Dividend and sinking fund $_{\text {Debt only }}$ & 16 & 3.9 \\
Debt and sinking fund & 1 & 0.2 \\
Dividend and debt only & 7 & 1.7 \\
Dividend, debt, and sinking fund & 1 & 0.2 \\
\hline
\end{tabular}

${ }^{a}$ Other covenants include event-risk puts, deferred puts, interest rate triggers, and credit-sensitive debt.

(CSFD) for the 80 firms with a standard covenant. The loosest restrictions allowed senior debt to be as much as 62.5 percent of CNTA. The vast majority, however (all but two), limited senior debt to 50 percent or less of tangible assets. Future senior debt was limited to an average of 21.3 percent of CNTA.

In all indentures limiting both total and senior debt, the limitation on senior debt is the more binding. A limitation on senior debt does not provide as much creditor protection, however, as a limitation on all funded debt. ${ }^{35}$ Thus, these traditional covenants are not written for maximum effectiveness in creditor protection.

Table 11 shows the incidence of sample covenants falling into specific subsets. These subsets are defined by the presence or absence of covenants involving sinking funds, limitations on debt or dividends, puts, interest rate triggers, and credit sensitivity. The call provision, negative pledge, and restriction on sale/leaseback are not specifically examined.

- Changes in covenant protection over time. Has covenant protection changed in modern times? To allow examination of this issue, the sample was partitioned into three groups-95 debentures issued between 1960 and 1969, 148 debentures issued between 1970 and 1979, and 171 debentures issued between 1980 and March 1992 . Table 12 presents the frequencies of specific covenants and covenant sets in these three time periods.

\footnotetext{
${ }^{35}$ See Malitz and Cohn (1987) for a discussion of the effects of subordinated debt on senior creditors.
} 
TABLE 12. Characteristics of Covenants Grouped by Year of Issuance, 1960-92

\begin{tabular}{|c|c|c|c|c|c|c|}
\hline \multirow[b]{2}{*}{ Characteristic } & \multicolumn{2}{|c|}{$1960-69$} & \multicolumn{2}{|c|}{$1970-79$} & \multicolumn{2}{|c|}{$1980-92$} \\
\hline & Number & Percent & Number & Percent & Number & Percent \\
\hline Number of issues & 95 & 100.0 & 148 & 100.0 & 171 & 100.0 \\
\hline \multicolumn{7}{|l|}{ Covenants } \\
\hline Call & 95 & 100.0 & 148 & 100.0 & 123 & 71.9 \\
\hline Sinking fund (SF) & 95 & 100.0 & 148 & 100.0 & 101 & 59.1 \\
\hline Negative pledge & 81 & 85.3 & 141 & 95.3 & 161 & 94.2 \\
\hline Sale/leaseback & 56 & 58.9 & 129 & 87.2 & 149 & 87.1 \\
\hline Debt & 53 & 55.8 & 75 & 50.7 & 9 & 5.3 \\
\hline Dividend & 55 & 57.9 & 82 & 55.4 & 8 & 4.7 \\
\hline Other & 0 & 0.0 & 0 & 0.0 & 20 & 11.7 \\
\hline \multicolumn{7}{|l|}{ Covenant sets } \\
\hline No covenants & 0 & 0.0 & 0 & 0.0 & 50 & 29.3 \\
\hline SF only & 36 & 37.9 & 65 & 43.9 & 90 & 52.6 \\
\hline Some covenants & 59 & 62.1 & 83 & 56.1 & 31. & 18.1 \\
\hline Debt only & 0 & 0.0 & 0 & 0.0 & 1 & 0.6 \\
\hline Other only ${ }^{\mathrm{a}}$ & 0 & 0.0 & 0 & 0.0 & 18 & 10.4 \\
\hline \multicolumn{7}{|l|}{ Dividend and } \\
\hline debt only & 0 & 0.0 & 0 & 0.0 & 1 & 0.6 \\
\hline Debt and SF & 4 & 4.2 & 1 & 0.7 & 2 & 1.2 \\
\hline \multicolumn{7}{|l|}{ Dividend and } \\
\hline $\mathrm{SF}$ & 6 & 6.3 & 8 & 5.4 & 2 & 1.2 \\
\hline $\begin{array}{l}\text { Dividend, debt, } \\
\text { and SF }\end{array}$ & 49 & 51.6 & 74 & 50.0 & 5 & 2.9 \\
\hline Other and SF & 0 & 0.0 & 0 & 0.0 & 2 & 1.2 \\
\hline
\end{tabular}

ather includes deferred puts, poison puts, interest rate triggers, and credit-sensitive debt.

The table reveals that the use of a negative pledge has increased slightly since the 1960s. The sale/leaseback restriction has been included in almost 90 percent of debentures issued since 1970; it began to be a common covenant in 1975.

The incidence of all other covenants has declined since 1979. In both the 1960 s and 1970s, all the sample issues contained both a call provision and a sinking-fund requirement. Since 1979, 28 percent of issues have been noncallable and 41 percent have not contained a sinking-fund provision.

Many analysts think the RJR Nabisco LBO triggered increased covenant protection, but of the 44 debentures offered after October 1988, only 6 (13.6 percent) were callable and none contained a sinking fund. The low prevailing 
interest rates during this period may explain the lack of call provisions. The lack of a sinking-fund requirement is not so readily explained. Rather than providing more protection since 1988, debentures appear to be providing less.

Also striking is the change in the two restrictions thought to reduce adverse incentives and limit the agency cost of debt. Limitations on debt, included in approximately 53 percent of earlier issues ( 56 percent of issues from the $1960 \mathrm{~s}$ and 51 percent of those from the 1970s), were incorporated in only slightly more than 5 percent of the later debentures. Dividend restrictions, offered in approximately 56 percent of the earlier issues, were included in only 4.7 percent of the debentures offered after 1979. Only 20 of the 171 newer issues contained any of the innovative covenants; 7 addressed deferred puts, 1 an extendible note, 9 event-risk trigger puts, 1 an interest rate trigger, and 2 credit-sensitive debt.

Of the 67 debentures issued after the RJR Nabisco LBO, only 27 were eligible for inclusion in the sample. Examining the covenants of the remaining 40 long-term, senior debentures is interesting, however. Only 2 of these issues were callable, and only 1 had a sinking fund. None contained a dividend, debt, or other covenant. Of all 67 issues, 5 were callable, 1 required a sinking fund, 3 had deferred (not event-risk) puts, and 1 contained a put triggered by a change in control. The RJR event evidently had no effect on covenant protection; if anything, protection declined after it.

Combining the covenants into sets yields even more extraordinary results. In the 1960 s and $1970 \mathrm{~s}$, as Table 12 shows, every issue contained a sinking-fund requirement; after 1979, 29 percent of issues contained no covenants, and the percentage of issues with only a sinking-fund requirement increased from 38 in the 1960 s to 44 in the 1970 s and to 52 after 1979. Only one debenture issued after 1988 had a sinking-fund requirement.

Few of the debentures issued in any of the periods contained only a limitation on debt or a dividend restriction (with or without a sinking fund), which is consistent with agency theory. A dividend restriction requires investment, whereas a limitation on debt restricts investments that could systematically increase creditor risk. Of the issues from the 1960s and 1970s, however, 52 percent and 50 percent, respectively, contained both a limitation on debt and a dividend restriction combined with a sinking fund; only 2.9 percent ( 5 issues) offered in the 1980 s contained this set of covenants. Only 11 debentures from the 1980 s ( 6.5 percent of all issues) contained either a debt or a dividend limitation. Of those, 5 of the 8 dividend restrictions and 7 of the 9 limitations on future debt were nonstandard. ${ }^{36}$

\footnotetext{
${ }^{36}$ The nonstandard dividend restrictions did not create an inventory of payable funds. Rather, they set net-worth limitations, which were extremely loose and unlikely to be binding. The
} 
"Other" covenants (event-risk, credit-sensitive, and put covenants) are all new forms since 1979. Most of the "other" covenants in the sample were deferred puts that provided protection only against rising interest rates.

- Characteristics of issues and issuing firms by covenant sets. One explanation for the decrease in the incidence of covenants since 1979 may be that the characteristics of the debentures and the offering firms have changed so that less protection is required than in the past. This explanation was tested by dividing issues into those with and without restrictive covenants and examining the characteristics of the issuing firms. The 173 issues with a restriction on dividends or future debt, a put, an interest rate trigger, or credit sensitivity were categorized as covenant protected. The 241 issues with no covenants or with only a sinking-fund requirement were categorized as unprotected. Table 13 presents the characteristics of the sample issues partitioned into these sets.

The table shows that debentures with restrictive covenants tended to have shorter maturities than unrestricted issues. Approximately 93 percent of the protected debentures were to mature in 25 years or less, compared with fewer than 40 percent of the latter. The protected issues also carried lower (Moody's) bond ratings than the unprotected issues. Only 8 percent of the restricted issues were rated high grade, compared with 41.5 percent of the unrestricted bonds. Approximately 62 percent of the restricted debentures and 47 percent of the unrestricted debentures were issued to repay debt. Restricted debentures were also less likely than unrestricted ones to have been issued for general purposes.

Finally, the difference in underwriter prestige between the two types of issues is noticeable in Table 13. A larger proportion of underwriters of the unrestricted issues (67.2 percent) came from the most prestigious set than underwriters of the restricted issues (only 55 percent).

Table 14 characterizes the firms issuing the 387 debentures for which data were available grouped by protected or unprotected issue status. The most striking difference between firms offering debentures with restrictions and those offering unrestricted debentures is size. Firms without restrictions were, on average, almost three times larger than those with covenants. This difference remains even after firm size is adjusted for changes in the price level. The sample contained a few extremely large firms, however, which may be skewing the results. The size difference is less evident in other comparisons. The median restricted/protected firm, for example, had price-adjusted total assets of $\$ 348$ million, compared with $\$ 462$ for the median unrestricted/

nonstandard limitations on debt did not restrict either CFD or CSFD. Most commonly, they were applied to subsidiaries (thereby allowing debt creation by the parent company) or restricted short-term debt (notes payable and installment notes). 
TABLE 13. Characteristics of Issues Grouped by Protection, 1960-92

\begin{tabular}{|c|c|c|c|c|}
\hline \multirow[b]{2}{*}{ Characteristic } & \multicolumn{2}{|c|}{ Unprotected Debentures } & \multicolumn{2}{|c|}{ Protected Debentures } \\
\hline & Number & Percent & Number & Percent \\
\hline Number of issues & 241 & 100.0 & 173 & 100.0 \\
\hline \multicolumn{5}{|l|}{ Years to maturity } \\
\hline $15-18$ & 2 & 0.8 & 9 & 5.2 \\
\hline 20 & 26 & 10.8 & 27 & 15.6 \\
\hline 25 & 68 & 28.2 & 125 & 72.3 \\
\hline 30 & 145 & 60.2 & 10 & 5.8 \\
\hline 40 & 0 & 0.0 & 2 & 1.1 \\
\hline \multicolumn{5}{|l|}{ Rating at issuance } \\
\hline High grade (AAA-AA) & 100 & 41.5 & 14 & 8.1 \\
\hline Medium grade (A-BAA) & 139 & 57.7 & 149 & 86.1 \\
\hline Low grade $(<\mathrm{BAA})$ & 2 & 0.8 & 6 & 3.4 \\
\hline Unrated & 0 & 0.0 & 4 & 2.4 \\
\hline \multicolumn{5}{|l|}{ Purpose of issue } \\
\hline Repay short-term debt & 78 & 35.8 & 72 & 41.6 \\
\hline Repay long-term debt & 24 & 11.0 & 35 & 20.2 \\
\hline Investment & 46 & 21.1 & 37 & 21.4 \\
\hline General purposes & 69 & 31.6 & 25 & 14.5 \\
\hline No purpose given & 1 & 0.5 & 4 & 2.3 \\
\hline \multicolumn{5}{|l|}{ Underwriter } \\
\hline High prestige (9) & 162 & 67.2 & 95 & 54.9 \\
\hline Lower prestige $(<9)$ & 79 & 32.8 & 78 & 45.1 \\
\hline
\end{tabular}

unprotected firm. The quartile of the smallest firms had price-adjusted total assets of $\$ 201$ million (restricted) and $\$ 232$ million (unrestricted). The size difference is most evident in the quartile of largest firms $-\$ 703$ million for firms with and $\$ 1.056$ billion for firms without debenture restrictions.

Firms offering covenants differed in virtually all characteristics from those not offering covenants. Their issues were larger, whether measured relative to total capital or total debt; they were more highly levered prior to the issuance of the debt; and they had even more funded debt as a percentage of capital afterwards. They were less profitable and had fewer fixed assets, lower growth, and more risk. Not surprisingly, issuing costs were higher for the restricted debentures than for the unrestricted ones.

In general, this study indicates that restrictive covenants tend to be associated with small firms with more risk, less profitability, and less established reputation 


\section{TABLE 14. Characteristics of Issuing Firms by Covenant Set, 1960-91}

\begin{tabular}{lrr}
\hline Characteristic & $\begin{array}{c}\text { Unprotected } \\
\text { Debentures }\end{array}$ & $\begin{array}{r}\text { Protected } \\
\text { Debentures }\end{array}$ \\
\hline Number of issues & 218 & 169 \\
Size of firm (total assets; \$millions) & $4,709.317$ & $1,734.500$ \\
Price-adjusted firm size (\$millions) & $2,045.551$ & 783.556 \\
Ratio of amount of issue to: & & \\
$\quad$ Total capital & 0.067 & 0.127 \\
$\quad$ Total debt (including current issue) & 0.357 & 0.448 \\
Ratio of funded debt to capital & & \\
$\quad$ Prior to issue & 0.168 & 0.220 \\
$\quad$ After issue & 0.224 & 0.320 \\
Earnings profitability & 0.136 & 0.122 \\
Ratio of net fixed to total assets & 0.454 & 0.368 \\
Growth ratio (market value to book value of equity) & 2.009 & 1.589 \\
Risk (standard deviation of stock returns) & 0.075 & 0.086 \\
Issuing cost & 0.922 & 1.159 \\
\hline
\end{tabular}

Note: Only 387 of the 414 issues are reflected in this table.

than their larger peers. In analyzing the decrease in restrictions in the 1980s, therefore, the next step is to determine whether debenture-issuing firms have become larger, less risky, more profitable, and of better repute than in the past.

- Changes in issues and issuing firms. Table 15 compares the characteristics of the 243 debentures issued between 1960 and 1979 with those of the 171 debentures offered between 1980 and March 1992. Note that the earlier sample had a slightly shorter maturity, an average of 25 years, compared with 27 years for the 1980-92 bonds. Ratings in the two periods are similar, with only a slight increase in quality over time. In the earlier period, 29 percent of the issues were rated high grade at issuance (Moody's Aaa or Aa); in the later period, 26 percent were rated high grade at issuance. A slightly higher percentage of issues in the later period (73 percent versus 67 percent) were rated medium grade ( $\mathrm{A}$ or $\mathrm{Baa}$ ), and fewer issues (1 percent versus 4 percent) were rated less than investment grade or were unrated. ${ }^{37}$

${ }^{37}$ As noted previously, junk bonds of the 1980 s did not influence the sample characteristics because junk bonds, virtually all short-term issues and largely subordinated debt, did not meet the criteria for debt to be included in the sample. 
TABLE 15. Characteristics of Issues, 1960-79 versus 1980-92

\begin{tabular}{|c|c|c|c|c|}
\hline \multirow[b]{2}{*}{ Characteristic } & \multicolumn{2}{|c|}{$1960-79$} & \multicolumn{2}{|c|}{$1980-92$} \\
\hline & Number & Percent & Number & Percent \\
\hline Number of issues & 243 & 100.0 & 171 & 100.0 \\
\hline \multicolumn{5}{|l|}{ Years to maturity } \\
\hline $15-18$ & 5 & 2.1 & 6 & 3.5 \\
\hline 20 & 24 & 9.9 & 28 & 16.4 \\
\hline 25 & 172 & 70.8 & 21 & 12.2 \\
\hline 30 & 42 & 17.3 & 114 & 66.7 \\
\hline 40 & 0 & 0.0 & 2 & 1.2 \\
\hline \multicolumn{5}{|l|}{ Rating at issuance } \\
\hline High grade (AAA-AA) & 70 & 28.8 & 44 & 25.7 \\
\hline Medium grade (A-BAA) & 163 & 67.1 & 125 & 73.1 \\
\hline Low grade $(<\mathrm{BAA})$ & 6 & 2.5 & 2 & 1.2 \\
\hline Unrated & 4 & 1.6 & 0 & 0.0 \\
\hline \multicolumn{5}{|l|}{ Purpose of issue } \\
\hline Repay short-term debt & 111 & 45.7 & 44 & 25.7 \\
\hline Repay long-term debt & 45 & 18.5 & 16 & 9.4 \\
\hline Investment & 48 & 19.8 & 38 & 22.2 \\
\hline General purposes & 35 & 14.4 & 72 & 42.1 \\
\hline No purpose given & 4 & 1.6 & 1 & 0.6 \\
\hline \multicolumn{5}{|l|}{ Underwriter } \\
\hline High prestige (9) & 127 & 52.3 & 131 & 76.6 \\
\hline Lower prestige $(<9)$ & 116 & 47.7 & 40 & 23.4 \\
\hline
\end{tabular}

Most of the debentures in the earlier period (64 percent) were issued to repay short- or long-term debt. In the later period, most (64 percent) were issued to raise funds for investment or for general purposes. A large proportion (22 percent) of the more recent debt was issued to fund acquisitions or to defend against takeovers.

Finally, the proportion of debentures offered by high-quality underwriters increased after 1979. In the earlier period, approximately half the issues were offered by five of the most prestigious underwriters. Since 1979, however, more than three-quarters of the issues have been marketed by the most prestigious firms-despite the entry into the underwriting market of (the lower prestige) Drexel Burnham Lambert.

Table 16 lists the characteristics of the firms that issued the 387 debentures 
TABLE 16. Characteristics of Issuing Firms, 1960-79 versus 1980-91

\begin{tabular}{|c|c|c|c|c|}
\hline \multirow[b]{2}{*}{ Characteristic } & \multicolumn{2}{|c|}{$1960-79$} & \multicolumn{2}{|c|}{$1980-91$} \\
\hline & Mean & Median & Mean & Median \\
\hline \multicolumn{5}{|l|}{ Size of firm (total assets; } \\
\hline \$millions) & $1,564.540$ & 560.400 & $6,524.850$ & $3,066.450$ \\
\hline Price-adjusted firm size & & & & \\
\hline (\$millions) & $1,152.388$ & 461.995 & $2,070.499$ & 998.201 \\
\hline \multicolumn{5}{|l|}{ Ratio of amount of issue to: } \\
\hline Total capital & 0.113 & 0.089 & 0.059 & 0.051 \\
\hline $\begin{array}{l}\text { Total debt (including current } \\
\text { issue) }\end{array}$ & 0.468 & 0451 & 0277 & 0910 \\
\hline \multicolumn{5}{|l|}{ Ratio of funded debt to capital } \\
\hline Prior to issue & 0.175 & 0.135 & 0.217 & 0.193 \\
\hline After issue & 0.267 & 0.226 & 0.264 & 0.241 \\
\hline Earnings profitability & 0.127 & 0.121 & 0.134 & 0.133 \\
\hline Ratio of net fixed to total & & & & \\
\hline assets & 0.394 & 0.376 & 0.454 & 0.419 \\
\hline $\begin{array}{l}\text { Growth ratio (market value to } \\
\text { book value of equity) }\end{array}$ & 1.668 & 1.408 & 2.091 & 1.711 \\
\hline $\begin{array}{l}\text { Risk (standard deviation of } \\
\text { stock returns) }\end{array}$ & 0.079 & 0.072 & 0.081 & 0.078 \\
\hline Variability relative to market & 1.041 & 0.937 & 0.860 & 0.799 \\
\hline Issuing costs & 1.091 & 0.889 & 0.916 & 0.886 \\
\hline
\end{tabular}

Note: Only 387 of the 414 issues are reflected on this table-243 issues in the 1960-79 period and 144 in the 1980-91 period.

for which firm-specific data were available. Firm size (price-level adjusted) almost doubled between the 1960-79 and 1980-91 periods; total assets of the average firm rose from $\$ 1.152$ billion in the early period to $\$ 2.070$ billion. (The median rose from $\$ 462$ million to $\$ 998$ million.) Therefore, large size and reputation are possible explanations for the decrease in debt covenants in the 1980s. Large firms tend to have more established reputations than small firms and are less likely to need to offer debt with restrictive covenants.

Whereas firm size increased between the two periods, the size of issues as a percentage of total capital declined from 11 percent to 6 percent. Issue size as a percentage of the firm's total debt (including the current issue) declined from 47 percent in the 1960-79 period to 28 percent. Thus, although the ratio of funded debt to capital prior to debt issuance was higher in the later period ( 22 
percent versus 17.5 percent), debt-to-capital ratios after issuance were almost identical in the two periods.

Firms issuing debentures after 1979 tended to be slightly more profitable than 1960-79 issuing firms. The later firms had more net fixed assets and higher growth. Variability (risk) was approximately the same between the two periods, but variability of returns relative to the market declined. Issuing costs also declined after 1979, in part because of an increase in the quality of the issuing firms, of the issues themselves, and of their underwriters.

\section{Conclusions}

After the RJR Nabisco LBO, investors initially reacted by withdrawing from the bond market. Then, creditors began demanding protection in the form of specific event-risk covenants. Now, however, those covenants have all but disappeared, and few new covenants have arisen to replace them. Even since the market rebound in 1991, new debt has offered little or no covenant protection. Particularly notable is the disappearance of basic sinking-fund provisions in the sample debenture issues. Credit-sensitive debt made a promising appearance but soon departed the scene, perhaps because firms cannot see the advantage of such debt and creditors are reluctant to compensate firms for a low default risk if interest rates decline.

What is the explanation for the vanishing restrictive covenant? Based on the increase in the quality of issuing firms and issues since 1979, some decline in the use of restrictive debt covenants is to be expected. Traditional limitations on debt and dividends and traditional sinking funds are relatively inexpensive to write and monitor, however, and have historically provided adequate protection. Therefore, increased quality cannot fully explain the apparently total lack of creditor protection since 1988.

One explanation for the disappearance of covenants may be that investors no longer trust the legal system to enforce covenant protection. Beginning with the Bankruptcy Act of 1978, which created Chapter 11 reorganization, the courts have become increasingly unwilling to enforce some restrictions. Specifically, as Franks and Torous (1989) noted, enforcement of absolute priority has become the exception rather than the rule. Investors may simply be unwilling to pay a premium for protection that might never be upheld.

An alternative explanation for the lack of covenant protection in the 1980 s is that, with the market and the economy experiencing unprecedented growth, investors became totally focused on return. Traditional covenant protection, once considered common and generally upheld in court, was no longer required, and investors were unwilling to accept a lower yield in exchange for safety.

One thing is fairly evident: Traditional covenants such as debt and dividend 
limitations and sinking funds (and possibly credit-sensitive debt) are superior to event-risk triggers in protecting creditors. As the Marriott case showed, no matter what triggers are included, managements can always invent new ways of expropriating wealth in the name of shareholder maximization.

The lesson for creditors is to require protection or be willing to accept the consequences if debt value declines. Creditors cannot have it both ways. They must make a choice between high yield and decreased risk. Each potential creditor must decide which is more important and live with the decision. 


\section{References}

Alchian, A. 1965. "The Basis of Some Recent Advances in the Theory of Management of the Firm." Journal of Industrial Economics (November):30-41.

American Bar Foundation. 1971. Commentaries on Model Debenture Indenture Provisions 1965, Model Debenture Indenture Provisions All Registered Issues 1967 and Certain Negotiable Provisions Which May Be Included in a Particular Incorporating Indenture. Chicago: American Bar Foundation.

Asquith, P., and T. Wizman. 1990. "Event Risk, Wealth Redistribution and the Return to Existing Bondholders in Corporate Buyouts." Journal of Financial Economics (September):195-213

Berle, A.A., Jr., and G.C. Means. 1933. The Modern Corporation and Private Property. New York: MacMillan.

Black, F., and M. Scholes. 1973. "The Pricing of Options and Corporate Liabilities." Journal of Political Economy (May/June):637-54.

Brauer, G. 1983. "Evidence of the Market Value of Me-First Rules." Financial Management (Spring):11-18.

Brick, I., and L. Fisher. 1987. "Effects of Classifying Equity or Debt on the Value of the Firm under Tax Asymmetry." Journal of Financial and Quantitative Analysis (December):383-99.

Carter, R., and S. Manaster. 1990. "Initial Public Offerings and Underwriter Reputation." Journal of Finance (September):1045-67.

Eastman, W., and P.V. Viswanath. 1992. "Dealing with Bondholder Disposition: An Efficiency Rationale for Legal Complexity." Working Paper, Rutgers University.

Fama, E., and M. Miller. 1972. The Theory of Finance. New York: Holt, Rinehart and Winston.

Franks, J., and W. Torous. 1989. "An Empirical Investigation of U.S. Firms in Reorganization." Journal of Finance (July):747-69.

Hayes, S. 1971. "Investment Banking: Power Structure in Flux." Harvard Business Review (March/April):136-52.

Healy, P., and K. Palepu. 1990. "Effectiveness of Accounting-Based Dividend Covenants." Journal of Accounting and Economics (January):97-123.

Jensen, M. 1986. "Agency Costs of Free Cash Flow, Corporate Finance and Takeovers." American Economic Review (May):323-29.

Jensen, M., and W. Meckling. 1976. "Theory of the Firm: Managerial Behaviour, Agency Costs, and Ownership Structure." Journal of Financial Economics (October):305-60. 
Kahan, M., and B. Tuckman. 1993. "Private vs. Public Lending: Evidence from Covenants." Working paper, New York University.

Kalay, A. 1982. "Stockholder-Bondholder Conflict and Dividend Constraints." Joumal of Financial Economics (July):211-33.

Laber, G. 1992. "Bond Covenants and Foregone Opportunities: The Case of Burlington Northern Railroad Company." Financial Management (Summer):71-77.

McDaniel, M. 1988. "Bondholders and Stockholders." The Journal of Corporation Law (Winter): 205-315.

Malitz, I. 1986. "On Financial Contracting: The Determinants of Bond Covenants." Financial Management (Summer): 18-25.

_ 1982. "The Optimal Set of Bond Covenants: A Theoretical and Empirical Investigation." Dissertation, University of Maryland.

Malitz, I., and R. Cohn. 1987. "The Non-Equivalence of Subordinated Debt from the Senior Creditor's Standpoint: A Pedagogical Note." Journal of Financial Education (Fall):1-5.

Mitchell, K. 1991. "The Call, Sinking Fund, and Term-to-Maturity Features of Corporate Bonds: An Empirical Investigation." Joumal of Financial and Quantitative Analysis (June):201-22.

Myers, S. 1977. "Determinants of Corporate Borrowing." Journal of Financial Economics (November):147-76.

Roberts, G., and J. Viscione. 1984. "The Impact of Seniority and Security Covenants on Bond Yields: A Note." Journal of Finance (December):1597-1602.

Smith, C., and J. Warner. 1979. "On Financial Contracting: An Analysis of Bond Covenants." Journal of Financial Economics (June):117-61.

Thatcher, J. 1985. "The Choice of Call Provisions: Evidence of Agency Costs of Debt." Journal of Finance (June):549-61.

Warga, A., and I. Welch. 1990. "Bondholder Losses in Leveraged Buyouts." First Boston Working Paper Series (May).

Watts, R., and J. Zimmerman. 1986. Positive Accounting Theory. Englewood Cliffs, N.J.: Prentice Hall.

Wilson, R., and F. Fabozzi. 1990. The New Corporate Bond Market: A Complete and Insightful Analysis of the Latest Trends, Issues and Advances. Chicago: Probus. 